\title{
Deleted in malignant brain tumor 1 is secreted in the oviduct and involved in the mechanism of fertilization in equine and porcine species
}

\author{
Barbara Ambruosi $i^{1,2,3,4}$, Gianluca Accogli ${ }^{5}$, Cécile Douet ${ }^{1,2,3,4}$, Sylvie Canepa ${ }^{1,2,3,4}$, \\ Géraldine Pascal ${ }^{1,2,3,4}$, Philippe Monget ${ }^{1,2,3,4}$, Carla Moros $^{6}$, Uffe Holmskov ${ }^{7}$, \\ Jan Mollenhauer ${ }^{7,8}$, Catherine Robbe-Masselot ${ }^{9,10,11}$, Olivier Vidal ${ }^{9,10,11}$, \\ Salvatore Desantis ${ }^{5}$ and Ghylène Goudet ${ }^{1,2,3,4}$
}

${ }^{1}$ INRA, UMR 85, Physiologie de la Reproduction et des Comportements, 37380 Nouzilly, France, ${ }^{2}$ CNRS, UMR 7247, 37380 Nouzilly, France, ${ }^{3}$ Université François Rabelais, 37000 Tours, France, ${ }^{4}$ IFCE, 37380 Nouzilly, France,

${ }^{5}$ Veterinary Clinic and Animal Productions Unit, Department of Emergency and Organ Transplantation, University of Bari, 70010 Valenzano, Bari, Italy, ${ }^{6}$ Department of Cell Biology and Histology, Faculty of Medicine, University of Murcia, 30100 Murcia, Spain, ${ }^{7}$ Institute for Molecular Medicine, Department of Cardiovascular and Renal Research, University of Southern Denmark, DK-5000 Odense, Denmark, ${ }^{8}$ Lundbeckfonden Center of Excellence NanoCAN, University of Southern Denmark, DK-5000 Odense, Denmark, ${ }^{9}$ Université Lille Nord de France, 59000 Lille, France, ${ }^{10}$ USTL, UGSF, IFR 147, 59650 Villeneuve d'Ascq, France and ${ }^{11}$ CNRS, UMR 8576, 59650 Villeneuve d'Ascq, France

Correspondence should be addressed to G Goudet at INRA, UMR 85, Physiologie de la Reproduction et des Comportements; Email: ghylene.goudet@tours.inra.fr

\begin{abstract}
Oviductal environment affects preparation of gametes for fertilization, fertilization itself, and subsequent embryonic development. The aim of this study was to evaluate the effect of oviductal fluid and the possible involvement of deleted in malignant brain tumor 1 (DMBT1) on IVF in porcine and equine species that represent divergent IVF models. We first performed IVF after pre-incubation of oocytes with or without oviductal fluid supplemented or not with antibodies directed against DMBT1. We showed that oviductal fluid induces an increase in the monospermic fertilization rate and that this effect is canceled by the addition of antibodies, in both porcine and equine species. Moreover, pre-incubation of oocytes with recombinant DMBT1 induces an increase in the monospermic fertilization rate in the pig, confirming an involvement of DMBT1 in the fertilization process. The presence of DMBT1 in the oviduct at different stages of the estrus cycle was shown by western blot and confirmed by immunohistochemical analysis of ampulla and isthmus regions. The presence of DMBT1 in cumulus-oocyte complexes was shown by western blot analysis, and the localization of DMBT1 in the zona pellucida and cytoplasm of equine and porcine oocytes was observed using immunofluorescence analysis and confocal microscopy. Moreover, we showed an interaction between DMBT1 and porcine spermatozoa using surface plasmon resonance studies. Finally, a bioinformatic and phylogenetic analysis allowed us to identify the DMBT1 protein as well as a DMBT1-like protein in several mammals. Our results strongly suggest an important role of DMBT1 in the process of fertilization.
\end{abstract}

Reproduction (2013) 146 119-133

\section{Introduction}

Deleted in malignant brain tumor 1 (DMBT1) was first identified as a candidate tumor-suppressor gene for brain tumors (Mollenhauer et al. 1997). It was then proposed as a candidate tumor suppressor gene for lung and gastrointestinal tumors caused by homozygous deletions or by a lack of expression (Mori et al. 1999, Wu et al. 1999, Mollenhauer et al. 2000). DMBT1 is involved in epithelial differentiation and mucosal innate immunity by binding to a large panel of pathogens including
HIV (Mollenhauer et al. 2000, 2004, Ligtenberg et al. 2010, Madsen et al. 2010, Al-Awqati 2011).

The DMBT1 gene, located on human chromosome 10q26.13, encodes a secreted high-molecular-weight glycoprotein of the scavenger receptor cysteine-rich (SRCR) group B protein family (Mollenhauer et al. 1997). The protein is composed of 14 SRCR domains separated by SRCR-interspersed domains, which are subjected to interindividual polymorphism, two CUB $(\mathrm{Clr} / \mathrm{Cls}$ Uegf Bmp1) domains, and a zona pellucida (ZP) domain toward the C-terminus (Mollenhauer et al. 1999, 2002). 
The DMBT1 gene encodes orthologs in rabbit (hensin (Takito et al. 1999)), mouse (CRP-ductin (Cheng et al. 1996, Madsen et al. 2003) and vomeroglandin (Matsushita et al. 2000)), rat (ebnerin (Li \& Snyder 1995)), bovine (bovine gallbladder mucin (Nunes et al. 1995, Mollenhauer et al. 2001)), human (gp-340 in lung (Holmskov et al. 1997, 1999) and salivary agglutinin in saliva (Prakobphol et al. 2000, Ligtenberg et al. 2001)), and porcine (sperm binding glycoprotein (SBG; Teijeiro et al. 2012)) species. The pig SBG has been shown to be present in the oviduct, at the apical surface of isthmic and ampullar epithelial cells (Perez et al. 2006), to bind to the heads of pig sperm (Marini \& Cabada 2003) and to be involved in sperm selection in the oviduct (Teijeiro et al. 2008).

The oviduct is an essential organ in reproductive biology, as it supports gamete transport, maturation, capacitation, fertilization, early embryonic growth, and embryo transport to the uterus. Its role is of particular importance during the process of fertilization. Oviduct epithelial cells co-culture promotes in vitro production of embryos in human (Bongso et al. 1991, Kervancioglu et al. 1997), bovine (Chian \& Sirard 1995, Way et al. 1997, Martus et al. 1998), porcine (Romar et al. 2001, McCauley et al. 2003), deer (Locatelli et al. 2005), and dromedary (Khatir et al. 2004) species. Moreover, some oviductal proteins have been shown to interact with gametes and to improve efficiency of IVF in porcine (McCauley et al. 2003, Coy et al. 2008), bovine (Martus et al. 1998), human (O'Day-Bowman et al. 1996), and equine (Mugnier et al. 2009) species. Some of these proteins, such as osteopontin, have been identified (Hao et al. 2006, Goncalves et al. 2008, Monaco et al. 2009) in cattle and pigs and atrial natriuretic peptide A (Anderson et al. 1994, Zamir et al. 1995, Zhang et al. 2006) and oviductin (oviduct-specific glycoprotein; Martus et al. 1998, Buhi 2002, McCauley et al. 2003) in cattle, pigs, and humans.

Our aim was to evaluate a putative role of DMBT1 in the mechanisms of fertilization, particularly in the interaction between oocyte and spermatozoa. For this purpose, we used two models in which the oviductal secretions are of particular importance for fertilization: the porcine and equine species. In porcine species, IVF rates are higher than $80 \%$, and the reported levels of polyspermy after IVF often exceed 50\% (Abeydeera \& Day 1997, Funahashi \& Day 1997, Day 2000, Nagai et al. 2006). The exposure of oocytes to porcine oviductal epithelial cells or oviductal fluid before IVF improves the rate of monospermy (Romar et al. 2001, Coy et al. 2008). In equine species, IVF rates are low and no repeatable IVF technique is available yet (Palmer et al. 1991, Dell'aquila et al. 1996, Alm et al. 2001, Hinrichs et al. 2002, McPartlin et al. 2009). We have shown a beneficial effect of homologous and heterologous oviduct cells on equine IVF rates (Mugnier et al. 2009). Thus, we studied the role of DMBT1 in gamete interaction during equine and porcine fertilization.

\section{Materials and methods}

All procedures on animals were conducted in accordance with the guidelines for the care and use of laboratory animals issued by the French Ministry of Agriculture and with the approval of the ethical review committee (Comité d'Ethique en Expérimentation Animale Val de Loire) under the number 2011/6. All chemicals were purchased from Sigma-Aldrich unless otherwise indicated.

\section{Collection and preparation of porcine oviduct fluid}

\section{Collection of oviducts}

Genital tracts from gilts and sows were obtained from a commercial abattoir and transported to the laboratory at room temperature. The cyclic stage of females was assessed on the basis of ovarian morphology on both ovaries from the same female. Oviducts were classified as early follicular, mid follicular, late follicular, or luteal phase, according to the diameter of follicles and the presence of corpora lutea, as described previously (Carrasco et al. 2008). Porcine oviducts at the preovulatory or post-ovulatory stage were collected from slaughtered Meishan gilts from our experimental pigsty (Unité Expérimentale de Physiologie Animale de l'Orfrasière, UEPAO, Nouzilly, France). Adult cyclic gilts received a daily dose of $5 \mathrm{ml}$ Regumate $(20 \mathrm{mg} / \mathrm{gilt}$ per day of altrenogest, Intervet S.A., Angers, France) per os for 18 days. An i.v. injection of human chorionic gonadotropin (hCG, Chorulon, 500 IU/gilt, Intervet S.A.) was performed 3 days later. Gilts were killed $36 \mathrm{~h}$ after hCG injection ( $4 \mathrm{~h}$ before ovulation) or $46 \mathrm{~h}$ after hCG injection ( $6 \mathrm{~h}$ after ovulation). Equine oviducts were collected from mares slaughtered in a commercial abattoir; the cyclic stage of females was unknown. For both species, the two oviducts were immediately collected and transported to the laboratory within a few minutes at room temperature.

\section{Collection of oviductal fluid}

The oviducts were dissected free from surrounding tissues, transferred to Petri dishes on ice, and washed in Medium 199 with Earles Salts, $25 \mathrm{mM}$ HEPES, and $\mathrm{NaHCO}_{3}$ supplemented with $80 \mu \mathrm{g} / \mathrm{ml}$ gentamicin. The oviductal fluid from the ampulla was expelled by gentle squeezing using a sterile microscope slide. It was collected by aspiration with an automatic pipette by introducing the tip into the ampulla and making a manual ascendant pressure from the isthmus to the ampulla (Carrasco et al. 2008). After centrifugation at $10000 \mathrm{~g}$ for $15 \mathrm{~min}$, the supernatant containing secreted and intracellular components was immediately stored at $-20^{\circ} \mathrm{C}$ until use as 'oviductal fluid'.

\section{Collection and in vitro maturation of porcine and equine oocytes}

Equine and porcine immature cumulus-oocyte complexes (COCs) were collected from slaughtered mares and gilts. Ovaries were obtained from local slaughterhouses immediately after females were killed and transported to the laboratory within $2 \mathrm{~h}$ in $0.9 \%(\mathrm{w} / \mathrm{v}) \mathrm{NaCl}$ at $32-38{ }^{\circ} \mathrm{C}$. COCs were 
collected by aspiration as described previously (Goudet et al. 2000) and recovered under a stereomicroscope.

For in vitro maturation, porcine immature COCs were washed in Dulbecco's PBS solution (DPBS, Dulbecco A, Paris, France) supplemented with $25 \mu \mathrm{g} / \mathrm{ml}$ gentamicin and then in maturation medium. The maturation medium was Medium 199 with Earle's salts supplemented with $10 \mathrm{ng} / \mathrm{ml}$ epidermal growth factor (EGF), $400 \mathrm{ng} / \mathrm{ml}$ FSH (PRIMUFOL, Rhône Mérieux, Lyon, France), and $570 \mu \mathrm{M}$ cysteamine (Marchal et al. 2003). Porcine COCs were then cultured in a group of 30-40 for $44 \mathrm{~h}$ in $500 \mu \mathrm{l}$ maturation medium in an atmosphere of $5 \% \mathrm{CO}_{2}$ in air at $39{ }^{\circ} \mathrm{C}$ in $100 \%$ humidity.

For in vitro maturation, equine immature COCs were washed once in Medium 199 with Earle's Salts, 25 mM HEPES, and $\mathrm{NaHCO}_{3}$ supplemented with $20 \%$ (v/v) FCS and $25 \mu \mathrm{g} / \mathrm{ml}$ gentamicin and then once in maturation medium. The maturation medium was Medium 199 with Earle's salts supplemented with $20 \%$ (v/v) FCS and 50 ng/ml EGF (Goudet et al. 2000). Equine COCs were then cultured in a group of 20-30 for $26-30 \mathrm{~h}$ in $500 \mu \mathrm{l}$ maturation medium in an atmosphere of $5 \% \mathrm{CO}_{2}$ in air at $38.5{ }^{\circ} \mathrm{C}$ in $100 \%$ humidity.

After in vitro maturation, porcine and equine COCs were partially denuded by flushing in maturation medium and processed for pre-incubation as described below. Some porcine and equine COCs were immediately processed for assessment of nuclear status as described below.

\section{Preparation of equine and porcine spermatozoa}

Frozen porcine spermatozoa $\left(800 \times 10^{6} / \mathrm{ml}\right)$ from one ejaculate of three 'Pietrain $\times$ Large-White' boars were thawed at $37^{\circ} \mathrm{C}$ for $20 \mathrm{~s}$ and washed by centrifugation at $100 \mathrm{~g}$ for $10 \mathrm{~min}$ in Beltsville-Thawing-Solution (BTS; COBIPORC, Saint-Gilles, France). Motile spermatozoa were obtained by centrifugation of the pellet at $700 \mathrm{~g}$ for $30 \mathrm{~min}$ on a discontinuous gradient of Percoll (Amersham Pharmacia Biotech; $2 \mathrm{ml} \mathrm{45 \%}$ in BTS over $2 \mathrm{ml} \mathrm{90 \% ).} \mathrm{The} \mathrm{90 \%} \mathrm{Percoll} \mathrm{solution} \mathrm{contained} 80 \mathrm{mM}$ $\mathrm{NaCl}, 10 \mathrm{mM}$ HEPES, $3.1 \mathrm{mM} \mathrm{KCl}, 0.3 \mathrm{mM} \mathrm{NaH}_{2} \mathrm{PO}_{4}, 25 \mathrm{mM}$ $\mathrm{NaHCO}_{3}, 0.4 \mathrm{mM} \mathrm{MgCl}$, $2 \mathrm{mM} \mathrm{CaCl}$, and $21.6 \mathrm{mM}$ lactic acid (Eid et al. 1994, Parrish et al. 1995). Sperm cells collected at the bottom of the $90 \%$ fraction were washed by centrifugation at $100 \mathrm{~g}$ for $10 \mathrm{~min}$ in $4 \mathrm{ml}$ modified Trisbuffered medium (mTBM; Marchal et al. 2003). This medium contained $113.1 \mathrm{mM} \mathrm{NaCl}, 3 \mathrm{mM} \mathrm{KCl}, 10 \mathrm{mM} \mathrm{CaCl}_{2}, 20 \mathrm{mM}$ Tris (MP Biomedicals, Illkirch, France), $11 \mathrm{mM}$ glucose, $5 \mathrm{mM}$ sodium pyruvate, $1 \mathrm{mM}$ caffeine, and $0.1 \%$ BSA. The concentration of the pelleted spermatozoa was determined by counting on a Thoma chamber under a microscope (Olympus, IMT-2, Paris, France) and the spermatozoa were diluted at $10 \times 10^{6} / \mathrm{ml}$ in mTBM. The motility was visually evaluated under a microscope (Olympus, IMT-2).

Fresh equine semen was collected with a closed artificial vagina from two adult Welsh pony stallions of proven fertility from our experimental study (UEPAO). Semen was filtered through gauze, sperm motility was visually evaluated under light microscopy on a heated stage, and sperm concentration was assessed using a spectrophotometer (Ciba-Geigy, Basel, Switzerland). Then, $1 \mathrm{ml}$ semen was diluted in $2 \mathrm{ml}$ prewarmed non-capacitating modified Whittens medium
(MW; $100 \mathrm{mM} \mathrm{NaCl}, 4.7 \mathrm{mM} \mathrm{KCl}, 1.2 \mathrm{mM} \mathrm{MgCl} 2,5.5 \mathrm{mM}$ glucose (anhydrous), $22 \mathrm{mM}$ HEPES, $4.8 \mathrm{mM}$ lactic acid hemicalcium salt, and $1 \mathrm{mM}$ pyruvic acid, $\mathrm{pH}$ 7.25; McPartlin et al. 2009). Diluted sperm was transported to the laboratory (5 min) at $37^{\circ} \mathrm{C}$ and centrifuged in $15 \mathrm{ml}$ conical tubes at $100 \mathrm{~g}$ for $1 \mathrm{~min}$ at $37^{\circ} \mathrm{C}$ to remove particulate matter and dead spermatozoa. The supernatant was then transferred to a $14 \mathrm{ml}$ round-bottomed tube and centrifuged at $600 \mathrm{~g}$ for $5 \mathrm{~min}$ at $37^{\circ} \mathrm{C}$. The pellet was resuspended in $1.5 \mathrm{ml}$ non-capacitating pre-warmed $\mathrm{MW}$, and the concentration was determined by counting on a Thoma chamber under a microscope (Olympus, IMT-2). Spermatozoa were then diluted at $10 \times 10^{6} / \mathrm{ml}$ in capacitating pre-warmed $\mathrm{MW}$, which was a non-capacitating MW supplemented with $25 \mathrm{mM} \mathrm{NaHCO}$ and $7 \mathrm{mg} / \mathrm{ml}$ BSA, pH 7.25 (McPartlin et al. 2009). Spermatozoa were incubated in $500 \mu \mathrm{l}$ aliquots in polyvinyl alcohol-coated $5 \mathrm{ml}$ round-bottomed tubes at $37^{\circ} \mathrm{C}$ in a humidified atmosphere for $6 \mathrm{~h}$. The motility was visually evaluated under a microscope (Olympus, IMT-2) at the beginning and at the end of the incubation period. Spermatozoa were then diluted at $1 \times 10^{6} / \mathrm{ml}$ in capacitating MW supplemented with $5 \mathrm{mM}$ procaine to induce hyperactivation. Droplets of $100 \mu \mathrm{l}$ spermatozoa suspension were laid down onto culture dishes and covered with mineral oil.

\section{Pre-incubation of porcine and equine oocytes}

Pre-incubation with oviductal fluid collected at the post-ovulatory stage

Porcine oocytes were washed in mTBM. They were preincubated in droplets of $50 \mu \mathrm{lmTBM}$ or post-ovulatory oviductal fluid supplemented with 0,1 , or $2 \mathrm{mg} / \mathrm{ml}$ anti-gp340 antibodies for $30 \mathrm{~min}$ in an atmosphere of $5 \% \mathrm{CO}_{2}$ in air at $39{ }^{\circ} \mathrm{C}$ in $100 \%$ humidity. Pre-incubation with post-ovulatory oviductal fluid supplemented with preimmune serum was used as a negative control. The anti-gp340 antibody is directed against gp340, the human ortholog of DMBT1, and was kindly provided by Prof. $\cup$ Holmskov from the University of Odense, Denmark (Holmskov et al. 1997). Its specificity was confirmed by Holmskov et al. (1997). The preimmune serum was provided by Prof. U Holmskov.

Equine oocytes were washed in capacitating MW. They were pre-incubated in droplets of $50 \mu \mathrm{l}$ capacitating MW or postovulatory oviductal fluid supplemented with 0 or $2 \mathrm{mg} / \mathrm{ml}$ of anti-gp340 antibodies for $30 \mathrm{~min}$ in an atmosphere of $5 \% \mathrm{CO}_{2}$ in air at $38.5^{\circ} \mathrm{C}$ in $100 \%$ humidity. Pre-incubation with postovulatory oviductal fluid supplemented with preimmune serum was used as a negative control.

\section{Pre-incubation with human recombinant DMBT1}

Porcine oocytes were washed in mTBM. They were preincubated in droplets of $50 \mu \mathrm{lmTBM}$ supplemented with 0 , $0.01,0.1,1,10$, or $100 \mu \mathrm{g} / \mathrm{ml}$ human recombinant DMBT1 (hrDMBT1) for $30 \mathrm{~min}$ in an atmosphere of $5 \% \mathrm{CO}_{2}$ in air at $39^{\circ} \mathrm{C}$ in $100 \%$ humidity. The hrDMBT1 was kindly provided by Prof. C Robbe-Masselot from the University of Lille, France (End et al. 2005, Rossez et al. 2011). Owing to the low availability of equine ovaries in abattoirs and therefore of 
equine oocytes for experiments, the effect of pre-incubation of equine oocytes with hrDMBT1 was not tested.

\section{IVF of porcine and equine oocytes}

After pre-incubation, porcine oocytes were washed in mTBM and groups of 30-40 were transferred to droplets of $100 \mu \mathrm{l}$ mTBM. Then, $10 \mu \mathrm{l}$ spermatozoa diluted at $10 \times 10^{6} / \mathrm{ml}$ in mTBM were added to the oocytes and co-incubated for $24 \mathrm{~h}$ in an atmosphere of $5 \% \mathrm{CO}_{2}$ in air at $39{ }^{\circ} \mathrm{C}$ in $100 \%$ humidity. After pre-incubation, equine oocytes were washed in capacitating MW and groups of ten were transferred to droplets of $100 \mu \mathrm{l}$ spermatozoa suspension diluted at $1 \times 10^{6} / \mathrm{ml}$ and co-incubated for $24 \mathrm{~h}$ in an atmosphere of $5 \% \mathrm{CO}_{2}$ in air at $38.5^{\circ} \mathrm{C}$ in $100 \%$ humidity. To evaluate the activation rate, some equine oocytes were washed in capacitating $\mathrm{MW}$ and transferred to droplets of $100 \mu \mathrm{l}$ capacitating MW supplemented with $5 \mathrm{mM}$ procaine without spermatozoa and incubated for $24 \mathrm{~h}$ in an atmosphere of $5 \% \mathrm{CO}_{2}$ in air at $38.5^{\circ} \mathrm{C}$ in $100 \%$ humidity.

\section{Assessment of nuclear status}

After gamete co-incubation, oocytes were washed by aspiration in and out of a pipette in DPBS and fixed in $4 \%$ paraformaldehyde in DPBS for $1 \mathrm{~h}$ at room temperature. After washing in DPBS, oocytes were stained with $2.5 \mu \mathrm{M}$ bisbenzimide fluorescent dye (Hoechst 33342) in DPBS:glycerol $(1: 3 \mathrm{v} / \mathrm{v})$ and mounted on microscope slides. The slides were kept at $4{ }^{\circ} \mathrm{C}$ in darkness until observation. Oocytes were observed under an inverted epifluorescence microscope with a $365 \mathrm{~nm}$ excitation filter to assess the nuclear status.

Fertilization was defined by the presence of at least two pronuclei in the cytoplasm. Oocytes containing two pronuclei were considered monospermic, and oocytes containing more than two pronuclei were considered polyspermic. Oocytes with one pronucleus without sperm cells were considered activated oocytes. Oocytes with metaphase II and one polar body were considered mature non-fertilized oocytes. The fertilization rate was calculated as the percentage of oocytes containing at least two pronuclei (fertilized oocytes) with respect to the number of mature, activated, and fertilized oocytes. The monospermy rate was calculated as the percentage of oocytes containing two pronuclei with respect to the number of fertilized oocytes.

\section{Gel electrophoresis and immunoblotting}

In order to analyze the proteins in the equine and porcine oviducts, the protein concentration in oviductal fluids was evaluated using the CooAssay Protein Determination Small Kit (Interchim, Montluçon, France). Oviductal fluids were diluted in electrophoresis Laemmli buffer $(0.062 \mathrm{~mol} / \mathrm{l}$ Tris- $\mathrm{HCl}, \mathrm{pH}$ $6.8,5 \%(\mathrm{v} / \mathrm{v})$ glycerol, $1 \%(\mathrm{w} / \mathrm{v})$ SDS, $0.5 \%(\mathrm{w} / \mathrm{v})$ bromophenol blue and $2 \%(\mathrm{v} / \mathrm{v}) 2-\beta$-mercaptoethanol at final concentration) and boiled at $95^{\circ} \mathrm{C}$ for $3 \mathrm{~min}$.

In order to analyze the proteins in the porcine COCs, 200 COCs were diluted in a lysis buffer ( $\beta$-glycerophosphate $80 \mathrm{mM}$, EDTA $20 \mathrm{mM}, \mathrm{MgCl}_{2} 15 \mathrm{mM}$, HEPES $20 \mathrm{mM}$, and dithiothreitol $1 \mathrm{mM}$ ) supplemented with $0.2 \%$ protease inhibitors cocktail. They were frozen in liquid nitrogen and thawed at $25^{\circ} \mathrm{C}$ three times, diluted in electrophoresis Laemmli buffer, and boiled at $95{ }^{\circ} \mathrm{C}$ for $3 \mathrm{~min}$.

Proteins were separated using 6\% SDS-PAGE. Acrylamide/ bis-acrylamide (37.5-1) solution was purchased from Interchim. For each lane, $50 \mu \mathrm{g}$ total proteins from oviductal fluid, or $50 \mu \mathrm{g}$ hrDMBT1, or a volume equivalent to 5-100 COCs were loaded on the gel. The proteins were then transferred onto a PVDF membrane (hybond-P PVDF membrane transfer; Amersham Pharmacia Biotech) for 90 min at $4{ }^{\circ} \mathrm{C}$.

The membrane was washed with TBS $(1.21 \mathrm{~g} / \mathrm{l}$ Tris base and $9 \mathrm{~g} / \mathrm{l} \mathrm{NaCl}, \mathrm{pH}$ 7.4) containing $0.1 \%$ ( $/ \mathrm{v}$ ) Tween 20 (TBS-T), incubated overnight in blocking solution $(5 \%(\mathrm{w} / \mathrm{v})$ non-fat dry milk, $0.2 \%$ (v/v) IGEPAL, pH 7.4, in TBS), and incubated for $4 \mathrm{~h}$ with the primary antibodies (anti-gp340 antibodies) diluted $1 / 2000$ in TBS-T. The membrane was washed twice with TBS-T, incubated for $1 \mathrm{~h}$ in blocking solution, incubated for $1 \mathrm{~h}$ with peroxidase-conjugated secondary antibodies (donkey antirabbit IgG, GE Healthcare, VWR, Strasbourg, France) diluted $1 / 2000$ in blocking solution, and washed three times with TBS-T. The peroxidase activity was revealed using the ECL-Plus Western blotting detection system (GE Healthcare, VWR).

\section{Light microscopy and immunohistochemistry on oviduct sections}

After collection of the pig oviducts, tissue fragments $(1 \times 0.5 \mathrm{~cm})$ were cut from the ampulla and the isthmus regions. The tissue fragments were fixed overnight in $4 \%$ (w/v) phosphate-buffered paraformaldehyde at $4{ }^{\circ} \mathrm{C}$. After fixation, the tissues were washed and dehydrated in ethanol series, cleared in xylene, and embedded in paraffin wax. Then, $4 \mu \mathrm{m}$-thick sections were cut, submitted to de-waxing with xylene and hydration in an ethanol series of descending concentration, and stained with Mayer's hematoxylin and eosin (to study the general morphology) or processed for immunohistochemistry as follows.

De-waxed and rehydrated tissue sections were incubated for $30 \mathrm{~min}$ in a solution of $0.3 \%(\mathrm{v} / \mathrm{v}) \mathrm{H}_{2} \mathrm{O}_{2}$ in methanol to inhibit endogenous peroxidase activity. They were rinsed with PBS- $1 \%$ $(\mathrm{w} / \mathrm{v}) \mathrm{BSA}$, and non-specific binding sites for immunoglobulins were blocked by $5 \%(\mathrm{v} / \mathrm{v})$ normal goat serum (NGS) in PBSBSA for $30 \mathrm{~min}$. Sections were incubated for $2 \mathrm{~h}$ at $37{ }^{\circ} \mathrm{C}$ in a moist chamber with a 1:250 dilution of primary antibody antigp340 and then incubated for 30 min with diluted 1:50 biotinylated universal secondary antibody of Vectastain Elite ABC kit (Universal; Vector, Burlingame, CA, USA). After washing for 15 min in PBS-BSA, immunohistochemical visualization was obtained using the Vecta-lab 'Elite' (ABC) kit (Vector). Peroxidase activity was visualized by incubating with $0.01 \% \mathrm{H}_{2} \mathrm{O}_{2}$ and $0.05 \%$ diaminobenzidine tetrahydrochloride in $0.05 \mathrm{M}$ Tris buffer, $\mathrm{pH} 7.2$, for $5 \mathrm{~min}$ to reveal the brown immunoreactive cells. Finally, the sections were counterstained with hematoxylin, dehydrated, and mounted.

To confirm the specificity of the immunoreaction, the following control procedures were performed: i) replacement of primary antibody with NGS and ii) omission of the primary 
antibody incubation step. These procedures yielded no immunostaining (Fig. 1B1 and C1).

\section{Immunocytochemical staining and confocal laser scanning microscopy}

Immature oocytes, in vitro matured oocytes, and in vitro matured oocytes pre-incubated with oviductal fluid were partially denuded by flushing in DPBS. They were fixed in $4 \%(\mathrm{w} / \mathrm{v})$ paraformaldehyde in DPBS for $20 \mathrm{~min}$ at $37^{\circ} \mathrm{C}$, washed in DPBS, and kept at $4{ }^{\circ} \mathrm{C}$ in DPBS containing $0.05 \%$ $(\mathrm{v} / \mathrm{v})$ sodium azide $\left(\mathrm{NaN}_{3}\right)$ and $1 \mathrm{mM}$ phenylmethylsulphonyl fluoride. Nonspecific reactions were blocked by pre-incubation of oocytes for $2 \mathrm{~h}$ at room temperature in DPBS containing $2 \%(\mathrm{w} / \mathrm{v})$ BSA (A-7030). Oocytes were incubated overnight at $4{ }^{\circ} \mathrm{C}$ with anti-gp340 antibodies diluted 1:200 in DPBS containing $2 \%$ BSA, washed in DPBS containing $0.2 \%$ BSA, incubated for $2 \mathrm{~h}$ at $4{ }^{\circ} \mathrm{C}$ with AlexaFluor 488conjugated-anti-rabbit antibodies diluted 1:800 in DPBS containing $2 \%$ BSA, and washed in DPBS containing $0.2 \%$ BSA. Oocytes were then stained with $1 \mu \mathrm{g} / \mathrm{ml}$ bisbenzimide (Hoechst 33342) in DPBS containing $0.2 \%$ BSA for $5 \mathrm{~min}$, washed in DPBS three times, and mounted on microscope slides in Mowiol V4-88 $(133 \mathrm{mg} / \mathrm{ml}$; Hoechst, Frankfurt, Germany) and $n$-propyl gallate $(5 \mathrm{mg} / \mathrm{ml})$. The slides were kept at $4{ }^{\circ} \mathrm{C}$ in darkness until observation. Oocytes were observed under a confocal laser scanning microscope (LSM 700, Zeiss, Jena, Germany) with diodes of 488 and $405 \mathrm{~nm}$ wavelength. Controls were performed using no primary antibodies to ascertain the absence of non-specific binding or no secondary antibodies to ascertain the absence of autofluorescence.

\section{Surface plasmon resonance}

Preparation of spermatozoa

Frozen porcine spermatozoa (12 straws, $800 \times 10^{6} / \mathrm{ml}$ per straw) from one ejaculate of three 'Pietrain $\times$ Large-White'

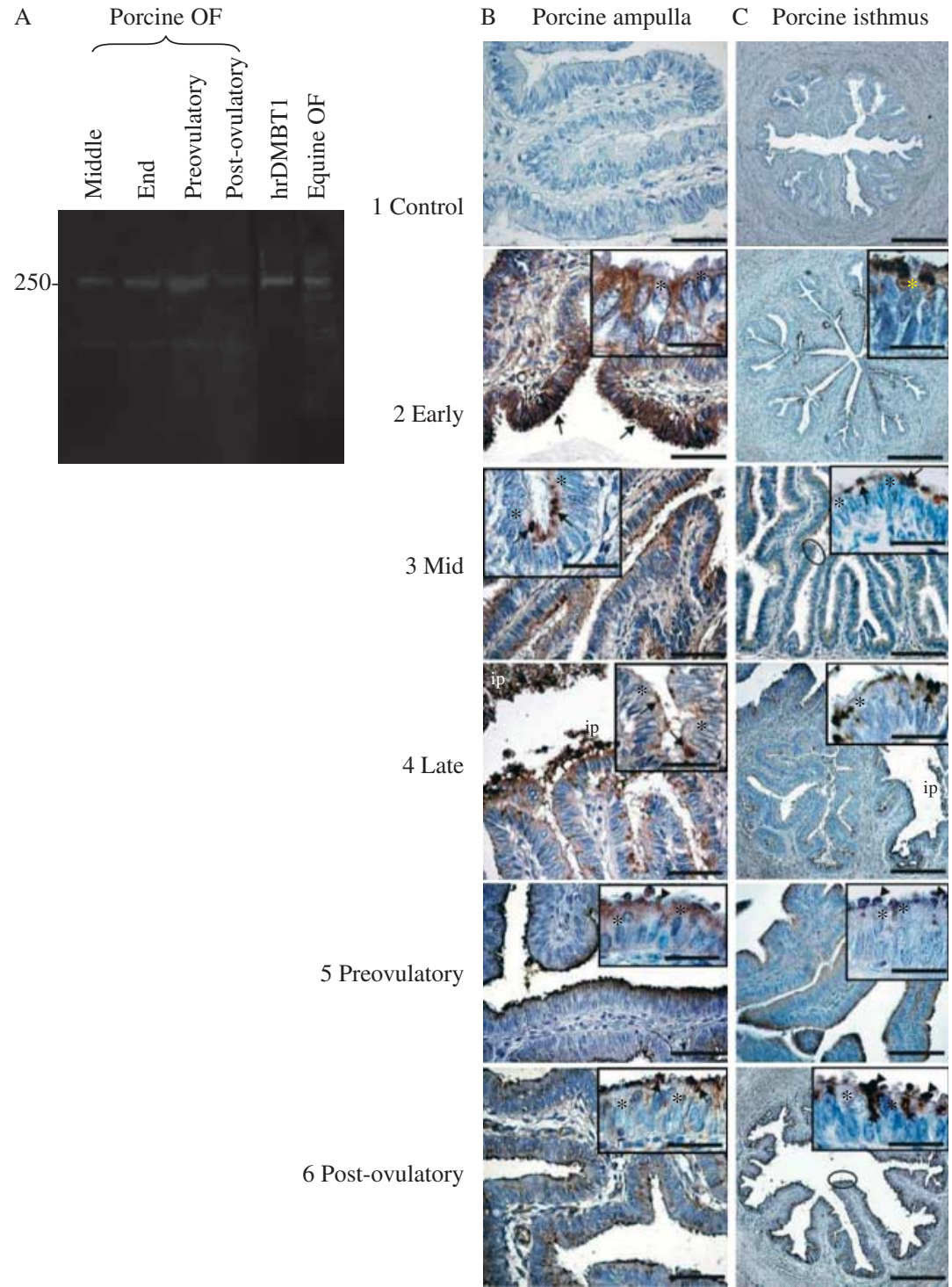

Figure 1 DMBT1 expression (A) in porcine and equine oviductal fluid (OF), hrDMBT1 was used as a positive control; DMBT1 localization in porcine ampulla (B2, B3, B4, B5 and B6) and porcine isthmus (C2, C3, C4, C5 and C6) sections collected at early follicular phase, mid follicular phase, late follicular phase, preovulatory stage $(4 \mathrm{~h}$ before ovulation), or post-ovulatory stage ( $6 \mathrm{~h}$ after ovulation); $\mathrm{B} 1$ and $\mathrm{C} 1$ show the negative control stainings; ip, intraluminal immunoreactivity; arrow, apical region of non-ciliated cells; arrow head, apical blebs; *, ciliated cells. Circles in C3 and C6 indicate the areas showed at high magnification in the insets. Scale bars: $\mathrm{B} 1=50 \mu \mathrm{m} ; \mathrm{B} 2=60 \mu \mathrm{m}$; $\mathrm{B} 3=60 \mu \mathrm{m} ; \mathrm{B} 4=55 \mu \mathrm{m} ; \mathrm{B} 5=60 \mu \mathrm{m} ; \mathrm{B} 6=55 \mu \mathrm{m}$; insets in $\mathrm{B} 2=30 \mu \mathrm{m} ; \mathrm{B} 3, \mathrm{~B} 4, \mathrm{~B} 5$ and $\mathrm{B} 6=40 \mu \mathrm{m}$; $\mathrm{C} 1=600 \mu \mathrm{m} ; \mathrm{C} 2=160 \mu \mathrm{m} ; \mathrm{C} 3$ and $\mathrm{C} 4=130 \mu \mathrm{m}$; $\mathrm{C} 5=100 \mu \mathrm{m} ; \mathrm{C} 6=500 \mu \mathrm{m}$; insets in $\mathrm{C} 2=35 \mu \mathrm{m}$; $\mathrm{C} 3, \mathrm{C} 4$ and $\mathrm{C} 5=40 \mu \mathrm{m} ; \mathrm{C} 6=30 \mu \mathrm{m}$. 
boars were thawed at $37^{\circ} \mathrm{C}$ for $20 \mathrm{~s}$, diluted in HBS $(10 \mathrm{mM}$ HEPES and $150 \mathrm{mM} \mathrm{NaCl}, \mathrm{pH} 7.4$ ), and centrifuged at $100 \mathrm{~g}$ for $10 \mathrm{~min}$ at $20^{\circ} \mathrm{C}$. Resulting pellets were pulled and resuspended in $10 \mathrm{ml} \mathrm{HBS}$ and centrifuged at $100 \mathrm{~g}$ for $10 \mathrm{~min}$. The pellet was resuspended in $10 \mathrm{ml} \mathrm{HBS}$ and subjected to nitrogen cavitation (10 min, 45 bar) in a cell disruption bomb (Flesch et al. 1998). The cavitate was slowly extruded into a tube containing $100 \mu \mathrm{l}$ protease inhibitors (Fermentas, Saint Remy les Chevreuses, France) and $100 \mu \mathrm{l}$ EDTA $0.05 \mathrm{M}$ and centrifuged at $1000 \mathrm{~g}$ for $10 \mathrm{~min}$ at $20^{\circ} \mathrm{C}$. The supernatant was centrifuged at $6000 \mathrm{~g}$ for $10 \mathrm{~min}$ at $20^{\circ} \mathrm{C}$, and the resulting supernatant was centrifuged at $110000 \mathrm{~g}$ for $3 \mathrm{~h} 30 \mathrm{~min}$ at $4{ }^{\circ} \mathrm{C}$. The pellet, containing sperm plasma membranes, was resuspended in HBS supplemented with $1 \%$ protease inhibitors and $0.05 \mathrm{M}$ EDTA and the supernatant was kept as a negative control. The protein content was evaluated with the BCA protein kit (Interchim) and samples were stored at $-80{ }^{\circ} \mathrm{C}$. The quality of the preparation of sperm plasma membranes was evaluated using transmission electron microscopy.

\section{Surface plasmon resonance}

Surface plasmon resonance experiments were performed on BIAcore T100 (GE Healthcare). The anti-gp340 antibodies were immobilized at a level of 1350 resonance units on two flow cells (FC) of a CM3 sensor chip (GE Healthcare), using standard amine coupling according to the manufacturer's instructions. One of the two FC was the test FC while the other was the control FC. Binding analyses were carried out at $25^{\circ} \mathrm{C}$. The hrDMBT1 was diluted at $6 \mu \mathrm{M}$ in the running buffer (DPBS complemented with $0.9 \mathrm{mM}$ calcium chloride and $0.5 \mathrm{mM}$ magnesium chloride) and injected for $600 \mathrm{~s}$ at a flow rate of $5 \mu \mathrm{l} / \mathrm{min}$ on the test FC. Porcine sperm plasma membrane preparations were sonicated on ice, filtered on Durapore filters $(0.2 \mu \mathrm{m})$, diluted at $20 \mu \mathrm{g} / \mathrm{ml}$ proteins in the running buffer, and injected for $600 \mathrm{~s}$ at a flow rate of $5 \mu \mathrm{l} / \mathrm{min}$ on the test FC and the control FC. The supernatant of the sperm plasma membrane preparations as well as a BSA solution $(20 \mu \mathrm{g} / \mathrm{ml})$ was injected under the same conditions as negative controls. Dissociation was studied over $600 \mathrm{~s}$. Regeneration of the surfaces was performed at a flow rate of $30 \mu \mathrm{l} / \mathrm{min}$ with two subsequent injections for $60 \mathrm{~s}$ of a solution containing $100 \mathrm{mM}$ HEPES, $1.5 \mathrm{M} \mathrm{NaCl}$, and $0.5 \%(\mathrm{v} / \mathrm{v})$ Tween 20 followed by an injection of a solution of $20 \mathrm{mM} \mathrm{NaOH}, 1 \mathrm{M} \mathrm{NaCl}$ for $60 \mathrm{~s}$, an injection of a solution of $50 \mathrm{mM} \mathrm{NaOH}, 1 \mathrm{M} \mathrm{NaCl}$ for $60 \mathrm{~s}$, and a stabilization for $120 \mathrm{~s}$.

\section{Identification and phylogeny of DMBT1 proteins in mammals}

To broaden the study to other mammals, we searched for the presence of DMBT1 proteins for human, chimpanzee, mouse, rat, bovine, horse, pig, and dog species in UniProtKB databases (http://www.uniprot.org/). UniProtKB consists of two sections: Swiss-Prot, which is manually annotated and reviewed, and TrEMBL, which is automatically annotated and is not reviewed. The proteins that are manually annotated and reviewed were included directly. The proteins that are automatically annotated and not reviewed were compared with the previous ones using a Basic Local Alignment Search Tool (BLAST; Altschul et al. 1997) program to discard redundant data.

To identify other eventual DMBT1 proteins, we submitted for each species the amino acid sequences of DMBT1 to the tblastn Software against the genome. Tblastn takes a protein query sequence and compares it against a nucleotide database, which has been translated in all six reading frames. When we observed an alignment, the localization of the sequences on the chromosomes was visualized using MapViewer (http:// www.ncbi.nlm.nih.gov/mapview/) and the amino acid sequence was extracted from NCBI (http://www.ncbi.nlm.nih. gov/protein) or Ensembl databases (http://www.ensembl.org) (Flicek et al. 2012).

To make sure that DMBT1 and DMBT1-like proteins are two distinctive proteins, alignment of DMBT1 and DMBT1-like proteins for each species was performed. This was done using the Needle Software that builds Needleman-Wunsch global alignments of two sequences (http://mobyle.pasteur.fr; Neron et al. 2009).

Phylogenetic analyses were carried out using http://www. phylogeny.fr. Multiple sequence alignments were performed using the MUSCLE algorithm. Curation was performed using Gblocks with non-stringent selection parameters. Phylogenetic trees were reconstructed using BioNJ (neighbor joining) and PhyML (maximum of likelihood) methods. Bootstrap values were estimated with 100 replications and the tree was rooted on the opossum DMBT1 protein (ENSM ODP00000010153).

\section{Statistical analysis}

The fertilization and monospermy rates were compared among groups using $\chi^{2}$ analysis. Differences were considered statistically significant at $P<0.05$.

\section{Results \\ Pre-incubation of equine and porcine oocytes with oviductal fluid collected at the post-ovulatory stage}

In this experiment, the in vitro maturation rate of porcine oocytes was $74 \%$ (of the 498 oocytes cultured in vitro, 368 were mature). The fertilization rate of porcine oocytes pre-incubated with oviductal fluid $(70 \%$, $64 / 92)$ was similar to that of the control group $(65 \%$, 57/87) (Fig. 2A). In contrast, the monospermic fertilization rate was significantly higher in the oviductal fluid group $(77 \%, 49 / 64)$ compared with the control group (53\%, 30/57; $P<0.01)$ (Fig. 2B). The addition of antigp340 antibodies during porcine oocyte pre-incubation with oviductal fluid showed a significant decrease in the monospermic fertilization rate $(50 \%, 33 / 66$ with $1 \mathrm{mg} / \mathrm{ml}$ anti-gp340; 41\%, 23/56 with $2 \mathrm{mg} / \mathrm{ml}$ anti-gp340) compared with oviductal fluid $(77 \%, 49 / 64 ; P<0.01)$, canceling the positive effect of oviductal fluid (Fig. 2B). To make sure that the effect observed with anti-gp340 antibodies was specifically due to the antibodies, oocytes were pre-incubated with oviductal fluid 

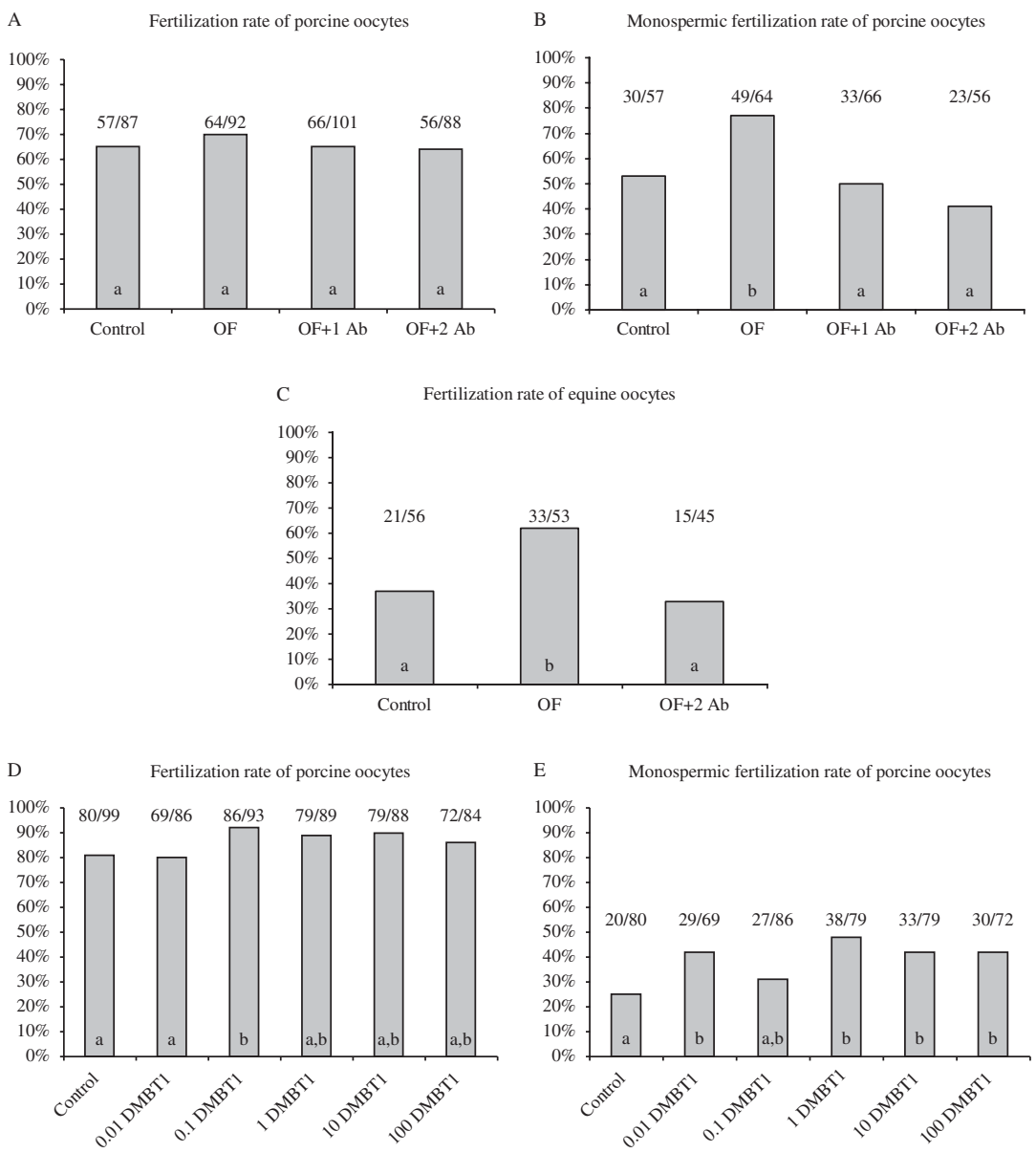

Figure 2 Fertilization rate $(\mathrm{A}$ and $\mathrm{C})$ and monospermic fertilization rate $(\mathrm{B})$ of porcine $(\mathrm{A}$ and $\mathrm{B})$ and equine $(\mathrm{C})$ oocytes pre-incubated in the control medium or in post-ovulatory oviductal fluid supplemented with $0 \mathrm{mg} / \mathrm{ml}(\mathrm{OF}), 1 \mathrm{mg} / \mathrm{ml}$ (OF + $1 \mathrm{Ab})$, or $2 \mathrm{mg} / \mathrm{ml}(\mathrm{OF}+2 \mathrm{Ab})$ anti-gp340 antibodies. The porcine monospermic fertilization rate was significantly higher in the oviductal fluid group compared with the control group, the addition of anti-gp340 antibodies showed a significant decrease in the monospermic fertilization rate compared with oviductal fluid. The equine fertilization rate was significantly higher in the oviductal fluid group compared with the control group, and the addition of anti-gp340 antibodies showed a significant decrease in the fertilization rate compared with the oviductal fluid. The porcine and equine fertilization rate and the porcine monospermic fertilization rate were not different between oocytes pre-incubated in oviductal fluid and oocytes pre-incubated in oviductal fluid supplemented with preimmune serum (data not shown). Fertilization rate (D) and monospermic fertilization rate (E) of porcine oocytes pre-incubated in the control medium supplemented with $0,0.01,0.1,1,10$, or $100 \mu \mathrm{g} / \mathrm{ml}$ human recombinant DMBT1. The addition of hrDMBT1 significantly increased the fertilization rate $(0.1 \mu \mathrm{g} / \mathrm{ml}$ hrDMBT1 $)$ and the monospermic fertilization rate $(0.01,1,10$, or $100 \mu \mathrm{g} / \mathrm{ml})$. The fractions represent the number of fertilized oocytes out of the number of mature, activated, and fertilized oocytes in (A, C and D), and the number of monospermic oocytes out of the number of fertilized oocytes in $(\mathrm{B})$ and $(\mathrm{E})$. Statistical differences are indicated by different letters $(P<0.05)$.

supplemented with preimmune serum. Their fertilization rate and their monospermic fertilization rate were similar to those for oocytes pre-incubated with oviductal fluid.

The in vitro maturation rate of equine oocytes was $61 \%$ (of the 254 oocytes cultured in vitro, 154 were mature). Equine oocytes pre-incubated with oviductal fluid showed a significant increase in the fertilization rate compared with that of the control group $(62 \%$, $33 / 53$ vs $37 \%, 21 / 56$ for oviductal fluid and control groups respectively; $P<0.01$; Fig. $2 \mathrm{C}$ ). The addition of $2 \mathrm{mg} / \mathrm{ml}$ anti-gp340 antibodies during equine oocyte pre-incubation with oviductal fluid showed a significant decrease in fertilization rates $(33 \%, 15 / 45$ for oviductal fluid and $2 \mathrm{mg} / \mathrm{ml}$ anti-gp340 vs $62 \%, 33 / 53$ for oviductal fluid; $P<0.01$ ), canceling the positive effect of oviductal fluid (Fig. 2C). To make sure that the effect observed with anti-gp340 antibodies was specifically due to the antibodies, oocytes were pre-incubated with oviductal fluid supplemented with preimmune serum. Their fertilization rate was not different from those for oocytes pre-incubated with oviductal fluid. All equine fertilized oocytes contained two pronuclei and no polyspermy was observed. When equine oocytes were incubated for $24 \mathrm{~h}$ in droplets of $100 \mu \mathrm{l}$ capacitating MW supplemented with $5 \mathrm{mM}$ procaine without spermatozoa, no activation was observed. 


\section{Pre-incubation of porcine oocytes with hrDMBT1}

To make sure that DMBT1 was really involved in the effect observed earlier, oocytes were pre-incubated with the recombinant molecule. In this experiment, the in vitro maturation rate of porcine oocytes was $81 \%$ (of the 664 oocytes cultured in vitro, 539 were mature). The fertilization rate of porcine oocytes pre-incubated with $0.1 \mu \mathrm{g} / \mathrm{ml}$ of hrDMBT1 $(92 \%, 86 / 93)$ was significantly higher than the control group (81\%, 80/99; $P<0.02$ ) (Fig. 2D). The monospermic fertilization rate was significantly higher for porcine oocytes preincubated with $0.01 \mu \mathrm{g} / \mathrm{ml}(42 \%, 29 / 69), 1 \mu \mathrm{g} / \mathrm{ml}(48 \%$, $38 / 79), 10 \mu \mathrm{g} / \mathrm{ml}(42 \%, 33 / 79)$, or $100 \mu \mathrm{g} / \mathrm{ml}(42 \%, 30 / 72)$ DMBT1 compared with the control group $(25 \%, 20 / 80$; $P<0.003$ ) (Fig. 2E).

\section{Presence of DMBT1 in the equine and porcine oviduct and localization in the porcine oviduct}

We analyzed the presence of DMBT1 using gel electrophoresis and immunoblotting in equine oviductal fluids collected at an unknown stage of the estrus cycle and in porcine oviductal fluids collected in the ampulla from females killed in the middle of follicular phase, at the end of follicular phase, at the preovulatory stage ( $4 \mathrm{~h}$ before ovulation), or at the post-ovulatory stage (6 $\mathrm{h}$ after ovulation). The antibody raised against DMBT1 revealed a band in equine and porcine samples, and in the four stages of the estrus cycle (Fig. 1A). The bands were close to $340 \mathrm{kDa}$, at the level of the band obtained for hrDMBT1 (Fig. 1A).

We analyzed the localization of DMBT1 using immunohistochemistry and light microscopy on porcine oviduct sections. The data obtained on the ampulla sections are presented in Fig. 1B. The DMBT1 antiserum immunoreacted with cells of the epithelium lining the ampulla mucosal folds. Staining was observed mainly in non-ciliated cells, but also in other cell types. The immunostaining pattern was different in the different estrous cycle stages. At the beginning of the follicular phase, epithelial cells of the upper zone of some mucosal folds expressed immunoreactivity in the entire cytoplasm (Fig. 1B2). In the middle phase, DMBT1 was expressed throughout the lining epithelium in the apical region of the epithelial cells (Fig. 1B3). These cells displayed immunoreactivity from the supra-nuclear region to luminal surface during the final follicular phase. Immunopositive material was also present in the luminal microenvironment (Fig. 1B4). In the preovulatory phase, the epithelial cells throughout the lining epithelium showed immunostaining from supra-nuclear region to the apical region from where immunopositive apical blebs detached and fell into the lumen (Fig. 1B5). Finally, $6 \mathrm{~h}$ post-ovulation, the immunostaining was still present in the entire supra-nuclear region of epithelial cells but no immunoreactive apical blebs were found (Fig. 1B6).

The data obtained on the isthmus sections are presented in Fig. 1C. In the epithelium lining the mucosal folds of the isthmus, the antiserum immunoreacted mainly with the non-ciliated cells, as well as other cell types. At the beginning of follicular phase, DMBT1 was not expressed in the epithelial cells of the base of mucosal trabeculae (Fig. 1C2). The immunopositive epithelial cells showed staining mainly at the apical region (inset of Fig. 1C2). In the middle and final stages, DMBT1 was expressed in the apical region of epithelial cells, constituting also the base of mucosal trabeculae (Fig. 1C3 and C4). Particularly, in the final follicular phase, the epithelial cells secreted immunopositive substance, which accumulated in the lumen (Fig. 1C4). In the preovulatory phase, immunopositive blebs detached from the apical region of immunoreactive epithelial cells along the entire isthmus (Fig. 1C5), whereas after $6 \mathrm{~h}$ post-ovulation, a decrease in the number of immunopositive epithelial cells occurred (Fig. 1C6). The negative control stainings yielded no immunostaining (Fig. 1B1 and $\mathrm{C} 1$ ).

\section{Presence and localization of DMBT1 in the COCs}

In order to check for an interaction of DMBT1 on the COCs, porcine and equine oocytes were pre-incubated with oviductal fluid and processed for immunocytochemical staining using anti-gp340 antibodies and confocal laser scanning microscopy. In the pig, staining of both the ZP and the cytoplasm was observed for immature oocytes (with a germinal vesicle), in vitro matured oocytes (with a metaphase II and a polar body), and in vitro matured oocytes pre-incubated with oviductal fluid (Fig. 3A). Staining was also observed for cumulus cells whatever the stage of the oocyte (Fig. 3A). No labeling was observed in the absence of primary antibodies regardless of the group (Fig. 3A). No auto-fluorescence was observed in the absence of secondary antibodies. In the horse, as in the pig, staining of both the ZP and the cytoplasm was observed for immature and in vitro matured oocytes pre-incubated or not with oviductal fluid, as well as cumulus cells (data not shown). No labeling was observed in the absence of primary or secondary antibodies.

To confirm the presence of DMBT1 in the COCs, gel electrophoresis and immunoblotting were performed on porcine COCs collected from the ovaries of females killed in a commercial abattoir. In the lanes where 50 and 100 COCs have been loaded, the anti-gp340 antibodies revealed a band close to $340 \mathrm{kDa}$ (Fig. 3B). The low availability of equine ovaries in the abattoirs did not allow us to collect enough equine COCs for gel electrophoresis and immunoblotting. 

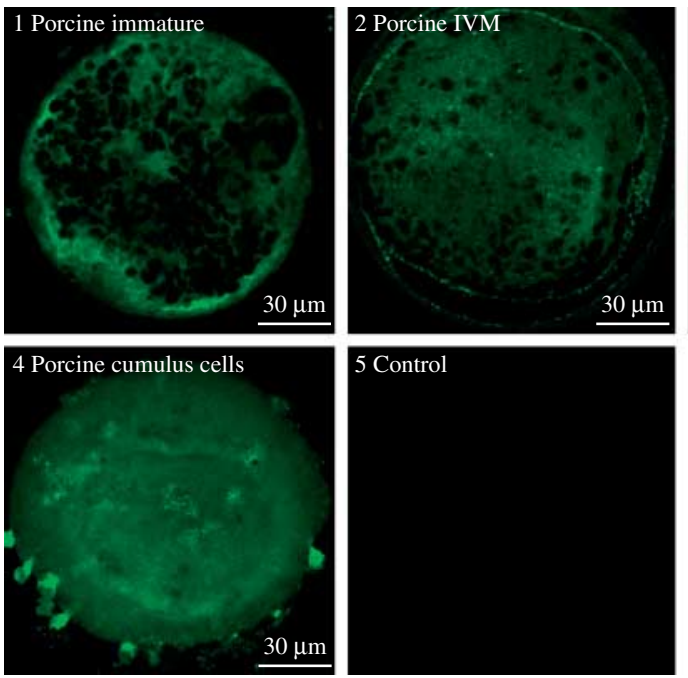

5 Control

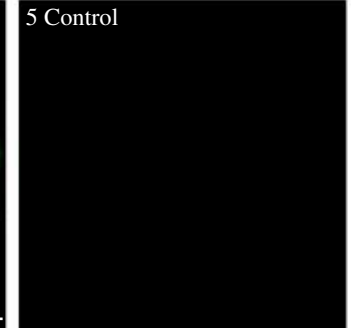

B

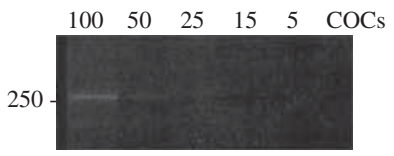

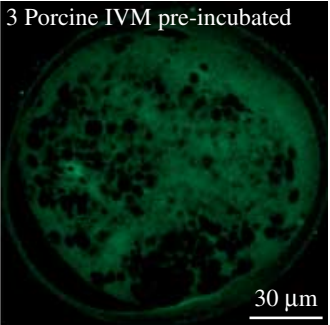

$30 \mu \mathrm{m}$

\section{Interaction of DMBT1 with porcine spermatozoa using surface plasmon resonance}

In order to check for an interaction between DMBT1 and spermatozoa, we performed surface plasmon resonance experiments. We showed that the injection of porcine sperm plasma membrane preparations on the test FC resulted in a binding to hrDMBT1 captured by the immobilized anti-gp340 antibodies (Fig. 4A). The same membrane preparation injected simultaneously into the control FC (immobilized anti-gp340 antibodies without pre-injection of hrDMBT1) resulted in a low non-specific binding signal (Fig. 4B). A low non-specific binding signal was also observed after the injection into the two FC of the supernatant of the sperm plasma membrane preparations (Fig. 4C and D) or the BSA solution (data not shown). These results show an interaction of DMBT1 with porcine sperm plasma membrane preparations.

\section{Identification and phylogeny of DMBT1 proteins in mammals}

To broaden the study to other mammals, we searched for the presence of DMBT1 proteins in databases. Table 1 shows an updated list of the DMBT1 proteins in human, chimpanzee, mouse, rat, bovine, horse, pig, and dog species. In all species, except the chimpanzee, two proteins were identified, generally called DMBT1 and DMBT1-like protein in the databases. In the chimpanzee, the tblastn of human DMBT1 vs chimpanzee genome showed two matches located on chromosome 10. The first one was called DMBT1 protein-like. For the second one (LOC745251), no amino acid sequence was found.

In all species, except the pig, the two $D M B T 1$ genes are located in a syntenic region on the same chromosome. In the pig, the two genes are located on chromosomes 6 and 14 respectively. The pig chromosome 14 region that contains DMBT1 also contains FAM24A-like (XP_003133260), which was also found in the syntenic region that contains $D M B T 1$ in other species.

To make sure that DMBT1 and DMBT1-like proteins are two distinct proteins, global alignments of DMBT1 and DMBT1-like proteins for each species were done. They showed low percentages of identity and low percentages of similarity (data not shown).

A first phylogenetic tree was reconstructed using all the sequences presented in Table 1 (data not shown). However, the phylogenetic tree and the multiple alignment data showed that the amino acid sequence of dogDMBT1-like (XP_548815) was highly divergent from the other sequences. Thus, this sequence was removed from the dataset of sequences used for new phylogenetic reconstructions. The phylogenetic trees obtained using BioNJ (Neighbor Joining) and PhyML (Maximum of Likelihood) methods are presented in Fig. 5. Both trees contain two groups of proteins, the DMBT1 protein and the DMBT1-like protein, each having a common ancestral gene. The branches of the DMBT1-like proteins are generally longer than the branches of the DMBT1 proteins. The so-called chimpanzee DMBT1-like protein is in the group of DMBT1 proteins, suggesting that this chimpanzee protein could be DMBT1 and should be 


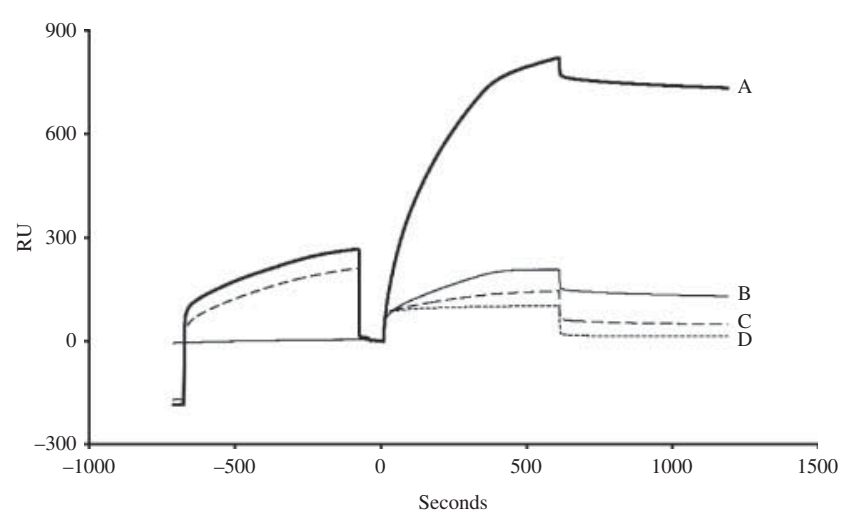

Figure 4 Surface plasmon resonance binding data. On the test flow cell (FC), $6 \mu \mathrm{M}$ hrDMBT1 were injected onto immobilized anti-gp340 antibodies, and then porcine sperm plasma membrane preparations (A) or the supernatant of the sperm plasma membrane preparations (C) were injected. In the control FC (immobilized anti-gp340 antibodies without pre-injection of hrDMBT1), porcine sperm plasma membrane preparations (B) or the supernatant of the sperm plasma membrane preparations (D) were injected. The test FC sensorgrams show a first association phase (increasing response) during the 600-s injection of hrDMBT1, followed by a second association phase during the 600-s injection of sperm membranes (A) or a low signal during the injection of the supernatant $(\mathrm{C})$, followed by a dissociation phase (decreasing response). The control FC sensorgrams show no signal in the first part, followed by a low signal during the injection of sperm membranes (B) or the supernatant (D).

reclassified as chimpanzee DMBT1. The pig DMBT1 gene located on chromosome 14 (ENSSSCP00000011425) is in the group of DMBT1-like proteins, suggesting that this gene encodes a DMBT1-like protein and should be reclassified as pig DMBT1-like.

\section{Discussion}

To our knowledge, this is the first study analyzing the role of DMBT1 in the mechanisms of fertilization. For this purpose, we decided to study two models, equine and porcine, that have different efficiencies in IVF rates. Our results suggest an involvement of DMBT1 in the fertilization process in both species. Our first objective was to evaluate the role of oviductal secretions in fertilization and the involvement of DMBT1 in this process.

In our conditions, pre-incubation of porcine and equine oocytes with oviductal fluid significantly increased monospermic IVF rates. These positive effects were canceled once anti-gp340 antibody was added to oviductal fluid, suggesting the involvement of DMBT1 (or a factor attached to DMBT1) in the fertilization process. This hypothesis has been confirmed after further experiments in which hrDMBT1 was used. In fact, preincubation of porcine oocytes with hrDMBT1 at different concentrations significantly increased both fertilization and monospermic fertilization rates. Owing to the low availability of equine ovaries in abattoirs and therefore of equine oocytes for experiments, we did not analyze the effect of pre-incubation of equine oocytes with hrDMBT1 on fertilization yet.

Our results confirm the beneficial effect of oviductal fluid showed in previous studies (Coy et al. 2008, Lloyd et al. 2009). These studies reported that exposure of oocytes to periovulatory oviductal fluid increased ZP resistance to proteolytic digestion and monospermic rates after IVF in porcine and bovine species. Moreover, pre-incubation of porcine oocytes increased cleavage and blastocyst developmental rates. These findings showed that oviductal fluid is capable of providing oocytes with components over a very short period of time between IVM and IVF, which benefit fertilization, embryo development, and embryo quality, and from our results, DMBT1 seems to be one of these components.

In previous studies, DMBT1 (previously called SBG in the pig) has been proposed to be implicated in sperm selection through acrosome alteration and suppression of motility of a subpopulation of sperm that have begun capacitation prematurely (Teijeiro et al. 2008, Teijeiro \& Marini 2012a). Using surface plasmon resonance experiments, we showed an interaction between DMBT1 and sperm plasma membrane preparations. Thus, from our results, we can provide new evidence on the relevance of this molecule during the fertilization process.

Our second aim was to clarify the role of DMBT1. We analyzed the expression of DMBT1 in the oviductal fluids, and we found that DMBT1 is present in both equine and porcine oviducts. Moreover, DMBT1 is present in the pig oviduct in all the examined stages of the estrus cycle. The presence of DMBT1 in the oviduct was then confirmed by immunohistochemical analysis. We analyzed the localization of DMBT1 in different sections of porcine oviduct (ampulla and isthmus) during the different estrous cycle stages. In both regions, the immunostaining was present mainly in non-ciliated cells, which are secretory cells mainly involved in the synthesis and release of glycoproteins that dissolve in the oviductal fluid (Buhi 2002, Abe \& Hoshi 2007, Desantis et al. 2011), but also in other cell types. The secretion of DMBT1 seems to follow the stages of the estrus cycle, as the presence of the protein is observed from the end of follicular phase in both isthmus and ampulla. This result is also confirmed by the observation that the immunoreactivity at the beginning of the follicular phase is in the cytoplasm and in the apical region of epithelial cells. From the middle of the follicular phase, then, it is mainly concentrated in the apical surface, indicating that cells are preparing for DMBT1 secretion. Moreover, we found that at the end of follicular stage and in the preovulatory phase, DMBT1 is present in the apical region of secretory cells as well as in the lumen of both ampulla and isthmus segments. The evidence that in the post-ovulatory stage, the expression of DMBT1 was found in the apical region of epithelial cells seems to show a continuous epithelium 
Table 1 Updated list of the DMBT1 proteins in mammals with their UniProt, GenBank, and Ensembl accession numbers and localization. For humans and rats, the accession numbers of the two longest transcripts have been mentioned.

\begin{tabular}{|c|c|c|c|c|c|}
\hline Species & Name of the protein & UniProtKB & GenBank & Ensembl & Localization \\
\hline Homo sapiens (human) & $\begin{array}{l}\text { Deleted in malignant brain } \\
\text { tumors } 1 \text { protein (the } \\
\text { gene has } 15 \text { transcripts) }\end{array}$ & Q9UGM3 & $\begin{array}{l}\text { XP_003403680 } \\
\text { BAA78577 }\end{array}$ & $\begin{array}{l}\text { ENSP00000357911 } \\
\text { ENSP00000342210 }\end{array}$ & $10 q 26.13$ \\
\hline H. sapiens (human) & $\begin{array}{l}\text { Putative DMBT1-like } \\
\text { protein }\end{array}$ & A6NE64 & & & $10 q 26.13$ \\
\hline $\begin{array}{l}\text { Pan troglodytes } \\
\text { (chimpanzee) }\end{array}$ & $\begin{array}{l}\text { Deleted in malignant brain } \\
\text { tumors } 1 \text { protein-like }\end{array}$ & & $\begin{array}{l}\text { XP_003339241 } \\
\text { XP_003312842 } \\
\text { XP_003312844 }\end{array}$ & ENSPTRP00000042778 & Chromosome 10 \\
\hline Mus musculus (mouse) & $\begin{array}{l}\text { Deleted in malignant brain } \\
\text { tumors } 1 \text { protein (the } \\
\text { gene has two transcripts) }\end{array}$ & Q60997 & $\begin{array}{l}\text { AĀ } 49835 \\
\text { BC049835 }\end{array}$ & $\begin{array}{l}\text { ENSMUSP00000006366 } \\
\text { ENSMUSP00000081556 }\end{array}$ & Chromosome 7 \\
\hline M. musculus (mouse) & $\begin{array}{l}\text { Putative DMBT1-like } \\
\text { protein }\end{array}$ & Q8BZE1 & & & Chromosome 7 \\
\hline Rattus norvegicus (rat) & $\begin{array}{l}\text { Deleted in malignant brain } \\
\text { tumors } 1 \text { protein (the } \\
\text { gene has six transcripts) }\end{array}$ & Q8CIZ5 & $\begin{array}{l}\text { NP_074040 } \\
\text { XP_003749045 }\end{array}$ & $\begin{array}{l}\text { ENSRNOP00000051794 } \\
\text { ENSRNOP00000027919 }\end{array}$ & Chromosome 1 \\
\hline R. norvegicus (rat) & $\begin{array}{l}\text { Deleted in malignant brain } \\
\text { tumors } 1 \text { protein-like }\end{array}$ & & XP_003749046 & & Chromosome 1 \\
\hline Bos taurus (bovine) & DMBT1 & F1MD73 & DAA14688 & ENSBTAP00000015890 & Chromosome 26 \\
\hline B. taurus (bovine) & $\begin{array}{l}\text { Deleted in malignant brain } \\
\text { tumors } 1 \text { protein-like }\end{array}$ & & XP_003584177 & & Chromosome 26 \\
\hline Equus caballus (horse) & $\begin{array}{l}\text { Deleted in malignant brain } \\
\text { tumors } 1 \text { protein }\end{array}$ & F6TJS5 & XP_001495444 & ENSECAP00000006236 & Chromosome 1 \\
\hline E. caballus (horse) & $\begin{array}{l}\text { Deleted in malignant brain } \\
\text { tumors } 1 \text { protein-like }\end{array}$ & & & ENSECAP00000016995 & Chromosome 1 \\
\hline Sus scrofa (pig) & $\begin{array}{l}\text { Deleted in malignant brain } \\
\text { tumors } 1 \text { protein }\end{array}$ & Q4A3R3 & $\begin{array}{l}\text { CAJ27171 } \\
\text { CAJ14977 } \\
\text { NP_001041653 }\end{array}$ & ENSSSCP00000003229 & Chromosome 6 \\
\hline S. scrofa (pig) & $\begin{array}{l}\text { Deleted in malignant brain } \\
\text { tumors } 1 \text { protein }\end{array}$ & F1SEE7 & XP_003133265 & ENSSSCP00000011425 & Chromosome 14 \\
\hline Canis lupus familiaris (dog) & $\begin{array}{l}\text { Deleted in malignant brain } \\
\text { tumors } 1 \text { protein (the } \\
\text { gene has three transcripts) }\end{array}$ & $\begin{array}{l}\text { F1PRV8 } \\
\text { F1PSK2 } \\
\text { F1PSL5 }\end{array}$ & XP_544052 & $\begin{array}{l}\text { ENSCAFP00000018537 } \\
\text { ENSCAFP00000018515 } \\
\text { ENSCAFP00000018502 }\end{array}$ & Chromosome 28 \\
\hline C. lupus familiaris (dog) & $\begin{array}{l}\text { Deleted in malignant brain } \\
\text { tumors } 1 \text { protein-like }\end{array}$ & & XP_548815 & & Chromosome 28 \\
\hline
\end{tabular}

secretion in order to guarantee an optimal oviductal environment to maintain the capacity of the isthmus for sperm selection and the ampulla for receiving oocytes.

In a previous study (Perez et al. 2006), immunohistochemical analysis of DMBT1 in oviducts obtained from gilts of approximately 120 days of age. Advances in in vitro production of pig embryos was performed. The results showed that DMBT1 localizes preferentially to the apical surface of epithelial cells, it is concentrated at the lumen rather than at the bottom of the folds and crypts of the fallopian tube, and there is a bigger amount of DMBT1 in the isthmus than in the ampulla. Our results are in agreement with these findings even if we did not find any difference between isthmus and ampulla. It is important to notice that the previous study was performed in the prepubertal stage and that they did not compare the different estrus cycle stages as we did in this study.

Immunofluorescence studies and confocal microscopy showed localization of DMBT1 in the ZP and cytoplasm of both porcine and equine oocytes, as well as cumulus cells. The presence of DMBT1 in porcine COCs was also confirmed by immunoblotting analysis. This is the first study, to our knowledge, in which the presence of DMBT1 in the oocytes has been analyzed.
These findings indicate that DMBT1 could act as a bridge between oocytes and sperm cells or oocytes and oviductal cells. DMBT1 could mediate their interaction by linking other associated proteins that can interact with DMBT1 and mediate its effect. DMBT1 has been shown to react with integrins, molecules that are involved in gamete interaction (Vijayakumar et al. 2008), and a recent study (Teijeiro \& Marini 2012b) showed that S100A7 (psoriasin), a protein localized at the head of sperm cells, interacts with DMBT1. Moreover, our results, obtained by surface plasmon resonance, showed an interaction between DMBT1 and porcine spermatozoa, giving more emphasis on this hypothesis.

Previous studies reported the hypothesis that DMBT1 is involved in sperm-negative selection, by damaging those spermatozoa that have begun capacitation when they arrive at the oviduct (Teijeiro et al. 2008, Teijeiro \& Marini 2012a). Our results add more information on the role of DMBT1 showing that it can be involved not only in this negative selection but also in pathways, such as fertilization, in which oocytes, sperm cells, and the oviduct are involved.

Our bioinformatics analyses allowed us to identify two distinctive proteins, generally called DMBT1 and 
A

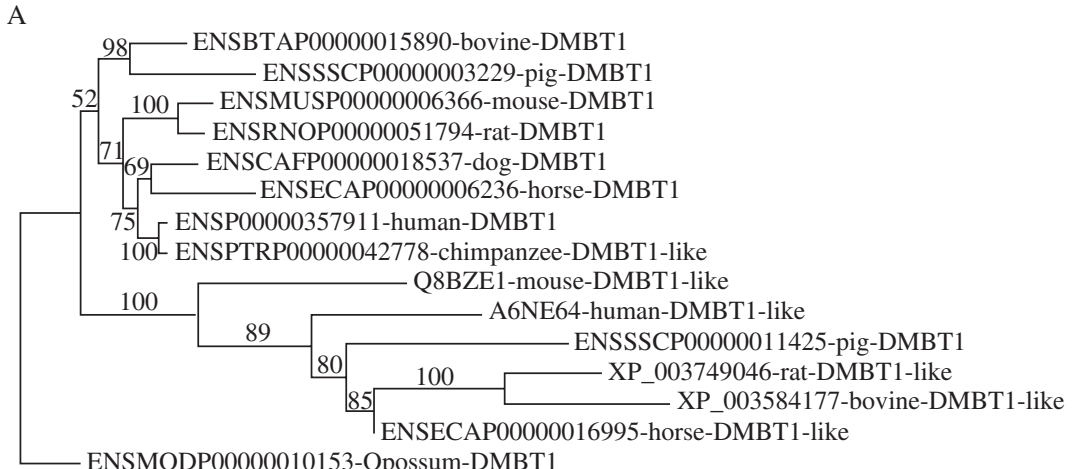

0.2

B
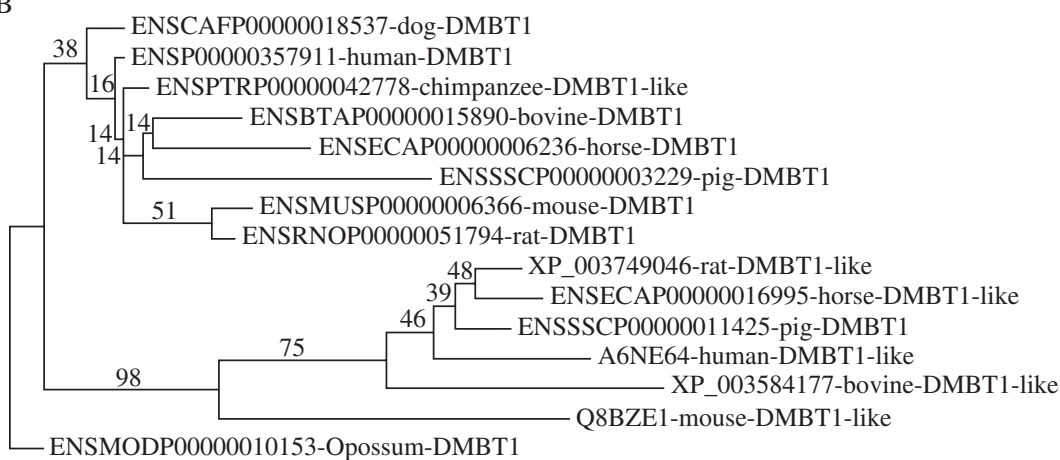

0.2
Figure 5 Phylogenetic trees of the DMBT1 proteins reconstructed using BioNJ (A) and PhyML (B) methods. Branch lengths indicate rates of evolution. The values at the tree nodes represent bootstrap values.
DMBT1-like in the databases, in human, mouse, rat, bovine, horse, and dog species. In the pig, the two proteins are called DMBT1. The pig DMBT1 genes are located on two different chromosomes, 6 and 14. The localization of the sequences on the chromosomes using MapViewer showed that the region of chromosome 14 containing the pig DMBT1 gene that encodes the protein ENSSSCP00000011425 also contains the gene FAM24A-like, as in the dog, cow, chimpanzee, mouse, and rat species. Moreover, the region of chromosome 6 containing the pig DMBT1 gene that encodes the protein ENSSSCP00000003229 also contains the spermadhesins PSP-I, PSP-II, AQN1, and $A W N 1$, as in the bovine species $(D M B T 1$ and DMBT1like genes are located close to the spermadhesins SPADH1 and SPADH2). This synteny analysis would suggest a breaking of synteny in the pig. According to the phylogenetic trees, we suggest that chromosome 6 contains the pig orthologous gene of the human $D M B T 1$ gene as the pig DMBT1 located on chromosome 6 (corresponding to ENSSSCP00000003229) shares a common ancestral gene with the other DMBT1 genes. The pig DMBT1 located on chromosome 14 (corresponding to ENSSSCP00000011425) shares a common ancestral gene with the other DMBT1-like genes. In all species except the pig, the two proteins are located on the same chromosome. Reconstruction of phylogenetic trees could suggest that $D M B T 1$ genes share a common ancestral gene and that $D M B T 1$-like genes share another common ancestral gene. The low percentages of identity and similarity between the DMBT1 and DMBT1-like proteins as well as the longer branches of the phylogenetic trees for the DMBT1-like proteins suggest that the $D M B T 1$-like genes have accumulated a high number of mutations during evolution. The evolution of this gene results probably from chromosomal rearrangements. Evolution of DMBT1-like genes could confer a specific role of the DMBT1-like protein, i.e. an alternative and/or complementary function to DMBT1 protein.

Finally, under our experimental conditions, we observed that during equine IVF, we obtained IVF rates of $62 \%$, after pre-incubation of oocytes with oviductal fluid. This result is interesting, considering that conventional IVF has only limited success in equine species (Palmer et al. 1991, Dell'aquila et al. 1996, Hinrichs et al. 2002, McPartlin et al. 2009, Mugnier et al. 2009). We chose the technique developed by McPartlin et al. (2009) in which spermatozoa were hyperactivated using procaine. In this study, they obtained IVF rates of $61 \%$ but their results do not seem to be repeatable, and we obtained $37 \%$ under the same conditions (our control group). A recent study (Ortgies et al. 2012) analyzed the effect of procaine, pentoxifylline, and trolox on capacitation and hyperactivation of stallion 
spermatozoa. Their findings showed that the combination of capacitating $\mathrm{MW}$ and procaine gave the best results for the induction of capacitation and hyperactivation in stallion spermatozoa. Our result is therefore encouraging for future successful IVF in equine species. Moreover, the improvement of monospermic fertilization rates that we observed in the pig is also encouraging in this species as polyspermy is still a problem.

In conclusion, we showed the involvement of DMBT1 in the fertilization process in the pig and the horse, its presence in the COCs, and confirmed and further analyzed its presence in the oviduct as well as an interaction between DMBT1 and spermatozoa. The presence of DMBT1 in other species such as human, mouse, rat, cattle, and dog allows us to hypothesize a role in the fertilization process in these species.

\section{Declaration of interest}

The authors declare that there is no conflict of interest that could be perceived as prejudicing the impartiality of the research reported.

\section{Funding}

This study was supported by the 'Institut Français du Cheval et de I'Equitation' (IFCE). B Ambruosi was financially supported by a post-doctoral grant from the 'Université François Rabelais de Tours'. C M Nicolás is supported by the Grant AGL200912512-C02-02.

\section{Acknowledgements}

The authors would like to thank Guy Duchamp, Eric Venturi, and the staff of the experimental stud and pigsty at the 'Unité Expérimentale de Physiologie Animale de l'Orfrasière $(\mathrm{UEPAO})^{\prime}$. They also thank Maryse Meurisse, Fabrice Vincent, Sophie Picard, Gaël Ramé, Thierry Delpuech, Pascal Papillier, Jean-Noël Couet, and the staff of the experimental slaughterhouse at the 'Unité Mixte de Recherche de Physiologie de la Reproduction et des Comportements (UMR PRC)' for technical help. They thank Thomas Loyau for his contribution to this work Sylvia Bedford-Guaus and Lori McPartlin at Cornell University (Ithaca, USA) for constructive discussion.

\section{References}

Abe H \& Hoshi H 2007 Regional and cyclic variations in the ultrastructural features of secretory cells in the oviductal epithelium of the Chinese Meishan pig. Reproduction in Domestic Animals 42 292-298. (doi:10.1111/j.1439-0531.2006.00781.x)

Abeydeera LR \& Day BN 1997 Fertilization and subsequent development in vitro of pig oocytes inseminated in a modified Tris-buffered medium with frozen-thawed ejaculated spermatozoa. Biology of Reproduction 57 729-734. (doi:10.1095/biolreprod57.4.729)

Al-Awqati Q 2011 Terminal differentiation in epithelia: the role of integrins in hensin polymerization. Annual Review of Physiology 73 401-412. (doi:10.1146/annurev-physiol-012110-142253)
Alm H, Torner H, Blottner S, Nurnberg G \& Kanitz W 2001 Effect of sperm cryopreservation and treatment with calcium ionophore or heparin on in vitro fertilization of horse oocytes. Theriogenology 56 817-829. (doi:10.1016/S0093-691X(01)00610-0)

Altschul SF, Madden TL, Schaffer AA, Zhang J, Zhang Z, Miller W \& Lipman DJ 1997 Gapped BLAST and PSI-BLAST: a new generation of protein database search programs. Nucleic Acids Research 25 3389-3402. (doi:10.1093/nar/25.17.3389)

Anderson RA, Feathergill KA, Drisdel RC, Rawlins RG, Mack SR \& Zaneveld LJ 1994 Atrial natriuretic peptide (ANP) as a stimulus of the human acrosome reaction and a component of ovarian follicular fluid: correlation of follicular ANP content with in vitro fertilization outcome. Journal of Andrology 15 61-70. (doi:10.1002/i.1939-4640.1994.tb01685.x)

Bongso A, Ng SC, Fong CY \& Ratnam S 1991 Improved fertilization rates of human oocytes in coculture. Journal of In Vitro Fertilization and Embryo Transfer 8 216-221. (doi:10.1007/BF01130808)

Buhi WC 2002 Characterization and biological roles of oviductspecific, oestrogen-dependent glycoprotein. Reproduction 123 355-362. (doi:10.1530/rep.0.1230355)

Carrasco LC, Romar R, Aviles M, Gadea J \& Coy P 2008 Determination of glycosidase activity in porcine oviductal fluid at the different phases of the estrous cycle. Reproduction 136 833-842. (doi:10.1530/REP08-0221)

Cheng H, Bjerknes M \& Chen H 1996 CRP-ductin: a gene expressed in intestinal crypts and in pancreatic and hepatic ducts. Anatomical Record 244 327-343. (doi:10.1002/(SICI)1097-0185(199603)244:3<327::AIDAR5 > 3.0.CO;2-V)

Chian RC \& Sirard MA 1995 Fertilizing ability of bovine spermatozoa cocultured with oviduct epithelial cells. Biology of Reproduction $\mathbf{5 2}$ 156-162. (doi:10.1095/biolreprod52.1.156)

Coy P, Canovas S, Mondejar I, Saavedra MD, Romar R, Grullon L, Matas C \& Aviles M 2008 Oviduct-specific glycoprotein and heparin modulate sperm-zona pellucida interaction during fertilization and contribute to the control of polyspermy. PNAS 105 15809-15814. (doi:10.1073/pnas. 0804422105)

Day BN 2000 Reproductive biotechnologies: current status in porcine reproduction. Animal Reproduction Science 60-61 161-172. (doi:10.1016/S0378-4320(00)00079-8)

Dell'aquila ME, Fusco S, Lacalandra GM \& Maritato F 1996 In vitro maturation and fertilization of equine oocytes recovered during the breeding season. Theriogenology 45 547-560. (doi:10.1016/0093691X(95)00402-T)

Desantis S, Zizza S, Accogli G, Acone F, Rossi R \& Resta L 2011 Morphometric and ultrastructural features of the mare oviduct epithelium during oestrus. Theriogenology 75 671-678. (doi:10.1016/j. theriogenology.2010.10.007)

Eid LN, Lorton SP \& Parrish JJ 1994 Paternal influence on S-phase in the first cell cycle of the bovine embryo. Biology of Reproduction 51 1232-1237. (doi:10.1095/biolreprod51.6.1232)

End C, Lyer S, Renner M, Stahl C, Ditzer J, Holloschi A, Kuhn HM, Flammann HT, Poustka A, Hafner M et al. 2005 Generation of a vector system facilitating cloning of DMBT1 variants and recombinant expression of functional full-length DMBT1. Protein Expression and Purification 41 275-286. (doi:10.1016/j.pep.2005.02.010)

Flesch FM, Voorhout WF, Colenbrander B, van Golde LM \& Gadella BM 1998 Use of lectins to characterize plasma membrane preparations from boar spermatozoa: a novel technique for monitoring membrane purity and quantity. Biology of Reproduction 59 1530-1539. (doi:10.1095/ biolreprod59.6.1530)

Flicek P, Amode MR, Barrell D, Beal K, Brent S, Carvalho-Silva D, Clapham P, Coates G, Fairley S, Fitzgerald S et al. 2012 Ensembl 2012. Nucleic Acids Research 40 D84-D90. (doi:10.1093/nar/gkr991)

Funahashi H \& Day BN 1997 Advances in in vitro production of pig embryos. Journal of Reproduction and Fertility. Supplement 52 271-283.

Goncalves RF, Chapman DA, Bertolla RP, Eder I \& Killian GJ 2008 Pre-treatment of cattle semen or oocytes with purified milk osteopontin affects in vitro fertilization and embryo development. Animal Reproduction Science 108 375-383. (doi:10.1016/j.anireprosci.2007.09.006)

Goudet G, Belin F, Mlodawska W \& Bezard J 2000 Influence of epidermal growth factor on in vitro maturation of equine oocytes. Journal of Reproduction and Fertility. Supplement 56 483-492. 
Hao Y, Mathialagan N, Walters E, Mao J, Lai L, Becker D, Li W, Critser J \& Prather RS 2006 Osteopontin reduces polyspermy during in vitro fertilization of porcine oocytes. Biology of Reproduction 75 726-733. (doi:10.1095/biolreprod.106.052589)

Hinrichs K, Love CC, Brinsko SP, Choi YH \& Varner DD 2002 In vitro fertilization of in vitro-matured equine oocytes: effect of maturation medium, duration of maturation, and sperm calcium ionophore treatment, and comparison with rates of fertilization in vivo after oviductal transfer. Biology of Reproduction 67 256-262. (doi:10.1095/ biolreprod67.1.256)

Holmskov U, Lawson P, Teisner B, Tornoe I, Willis AC, Morgan C, Koch C \& Reid KB 1997 Isolation and characterization of a new member of the scavenger receptor superfamily, glycoprotein-340 (gp-340), as a lung surfactant protein-D binding molecule. Journal of Biological Chemistry 272 13743-13749. (doi:10.1074/jbc.272.21.13743)

Holmskov U, Mollenhauer J, Madsen J, Vitved L, Gronlund J, Tornoe I, Kliem A, Reid KB, Poustka A \& Skjodt K 1999 Cloning of gp-340, a putative opsonin receptor for lung surfactant protein D. PNAS 96 10794-10799. (doi:10.1073/pnas.96.19.10794)

Kervancioglu ME, Saridogan E, Atasu T, Camlibel T, Demircan A, Sarikamis B \& Djahanbakhch O 1997 Human fallopian tube epithelial cell co-culture increases fertilization rates in male factor infertility but not in tubal or unexplained infertility. Human Reproduction 12 1253-1258. (doi:10.1093/humrep/12.6.1253)

Khatir H, Anouassi A \& Tibary A 2004 Production of dromedary (Camelus dromedarius) embryos by IVM and IVF and co-culture with oviductal or granulosa cells. Theriogenology 62 1175-1185. (doi:10.1016/j.theriogenology.2004.01.016)

Li XJ \& Snyder SH 1995 Molecular cloning of Ebnerin, a von Ebner's gland protein associated with taste buds. Journal of Biological Chemistry 270 17674-17679. (doi:10.1074/jbc.270.30.17674)

Ligtenberg TJ, Bikker FJ, Groenink J, Tornoe I, Leth-Larsen R, Veerman EC, Nieuw Amerongen AV \& Holmskov U 2001 Human salivary agglutinin binds to lung surfactant protein-D and is identical with scavenger receptor protein gp-340. Biochemical Journal 359 243-248. (doi:10.1042/0264-6021:3590243)

Ligtenberg AJ, Karlsson NG \& Veerman EC 2010 Deleted in malignant brain tumors-1 protein (DMBT1): a pattern recognition receptor with multiple binding sites. International Journal of Molecular Sciences $\mathbf{1 1}$ 5212-5233. (doi:10.3390/ijms1112521)

Lloyd RE, Romar R, Matas C, Gutierrez-Adan A, Holt WV \& Coy P 2009 Effects of oviductal fluid on the development, quality, and gene expression of porcine blastocysts produced in vitro. Reproduction 137 679-687. (doi:10.1530/REP-08-0405)

Locatelli Y, Cognie Y, Vallet JC, Baril G, Verdier M, Poulin N, Legendre X \& Mermillod P 2005 Successful use of oviduct epithelial cell coculture for in vitro production of viable red deer (Cervus elaphus) embryos. Theriogenology 64 1729-1739. (doi:10.1016/j.theriogenology.2005. 04.002)

Madsen J, Tornoe I, Nielsen $O$, Lausen $M$, Krebs I, Mollenhauer J, Kollender G, Poustka A, Skjodt K \& Holmskov U 2003 CRP-ductin, the mouse homologue of gp-340/deleted in malignant brain tumors 1 (DMBT1), binds gram-positive and gram-negative bacteria and interacts with lung surfactant protein D. European Journal of Immunology 33 2327-2336. (doi:10.1002/eji.200323972)

Madsen J, Mollenhauer J \& Holmskov U 2010 Review: Gp-340/DMBT1 in mucosal innate immunity. Innate Immunity 16 160-167. (doi:10.1177/ 1753425910368447)

Marchal R, Caillaud M, Martoriati A, Gerard N, Mermillod P \& Goudet G 2003 Effect of growth hormone $(\mathrm{GH})$ on in vitro nuclear and cytoplasmic oocyte maturation, cumulus expansion, hyaluronan synthases, and connexins 32 and 43 expression, and $\mathrm{GH}$ receptor messenger RNA expression in equine and porcine species. Biology of Reproduction 69 1013-1022. (doi:10.1095/biolreprod.103.015602)

Marini PE \& Cabada MO 2003 One step purification and biochemical characterization of a spermatozoa-binding protein from porcine oviductal epithelial cells. Molecular Reproduction and Development 66 383-390. (doi:10.1002/mrd.10361)

Martus NS, Verhage HG, Mavrogianis PA \& Thibodeaux JK 1998 Enhancement of bovine oocyte fertilization in vitro with a bovine oviductal specific glycoprotein. Journal of Reproduction and Fertility $\mathbf{1 1 3}$ 323-329. (doi:10.1530/jrf.0.1130323)
Matsushita F, Miyawaki A \& Mikoshiba K 2000 Vomeroglandin/CRP-ductin is strongly expressed in the glands associated with the mouse vomeronasal organ: identification and characterization of mouse vomeroglandin. Biochemical and Biophysical Research Communications 268 275-281. (doi:10.1006/bbrc.2000.2104)

McCauley TC, Buhi WC, Wu GM, Mao J, Caamano JN, Didion BA \& Day BN 2003 Oviduct-specific glycoprotein modulates sperm-zona binding and improves efficiency of porcine fertilization in vitro. Biology of Reproduction 69 828-834. (doi:10.1095/biolreprod.103.016444)

McPartlin LA, Suarez SS, Czaya CA, Hinrichs K \& Bedford-Guaus SJ 2009 Hyperactivation of stallion sperm is required for successful in vitro fertilization of equine oocytes. Biology of Reproduction 81 199-206. (doi:10.1095/biolreprod.108.074880)

Mollenhauer J, Wiemann S, Scheurlen W, Korn B, Hayashi Y, Wilgenbus KK, von Deimling A \& Poustka A 1997 DMBT1, a new member of the SRCR superfamily, on chromosome 10q25.3-26.1 is deleted in malignant brain tumours. Nature Genetics 17 32-39. (doi:10.1038/ng0997-32)

Mollenhauer J, Holmskov U, Wiemann S, Krebs I, Herbertz S, Madsen J, Kioschis P, Coy JF \& Poustka A 1999 The genomic structure of the DMBT1 gene: evidence for a region with susceptibility to genomic instability. Oncogene 18 6233-6240. (doi:10.1038/sj.onc.1203071)

Mollenhauer J, Herbertz S, Holmskov U, Tolnay M, Krebs I, Merlo A, Schroder HD, Maier D, Breitling F, Wiemann S et al. 2000 DMBT1 encodes a protein involved in the immune defense and in epithelial differentiation and is highly unstable in cancer. Cancer Research 60 1704-1710.

Mollenhauer J, Herbertz S, Helmke B, Kollender G, Krebs I, Madsen J, Holmskov U, Sorger K, Schmitt L, Wiemann S et al. 2001 Deleted in malignant brain tumors 1 is a versatile mucin-like molecule likely to play a differential role in digestive tract cancer. Cancer Research 61 8880-8886.

Mollenhauer J, Muller H, Kollender G, Lyer S, Diedrichs L, Helmke B, Holmskov U, Ligtenberg T, Herbertz S, Krebs I et al. 2002 The SRCR/SID region of DMBT1 defines a complex multi-allele system representing the major basis for its variability in cancer. Genes, Chromosomes \& Cancer 35 242-255. (doi:10.1002/gcc.10115)

Mollenhauer J, Helmke B, Medina D, Bergmann G, Gassler N, Muller H, Lyer S, Diedrichs L, Renner M, Wittig R et al. 2004 Carcinogen inducibility in vivo and down-regulation of DMBT1 during breast carcinogenesis. Genes, Chromosomes \& Cancer 39 185-194. (doi:10.1002/gcc.10309)

Monaco E, Gasparrini B, Boccia L, De Rosa A, Attanasio L, Zicarelli L \& Killian G 2009 Effect of osteopontin (OPN) on in vitro embryo development in cattle. Theriogenology 71 450-457. (doi:10.1016/j. theriogenology.2008.08.012)

Mori M, Shiraishi T, Tanaka S, Yamagata M, Mafune K, Tanaka Y, Ueo H, Barnard GF \& Sugimachi K 1999 Lack of DMBT1 expression in oesophageal, gastric and colon cancers. British Journal of Cancer $\mathbf{7 9}$ 211-213. (doi:10.1038/sj.bjc.6690035)

Mugnier S, Kervella M, Douet C, Canepa S, Pascal G, Deleuze S, Duchamp G, Monget P \& Goudet G 2009 The secretions of oviduct epithelial cells increase the equine in vitro fertilization rate: are osteopontin, atrial natriuretic peptide $\mathrm{A}$ and oviductin involved? Reproductive Biology and Endocrinology 7 129. (doi:10.1186/1477-7827-7-129)

Nagai T, Funahashi H, Yoshioka K \& Kikuchi K 2006 Up date of in vitro production of porcine embryos. Frontiers in Bioscience 11 2565-2573. (doi:10.2741/1991)

Neron B, Menager H, Maufrais C, Joly N, Maupetit J, Letort S, Carrere S, Tuffery P \& Letondal C 2009 Mobyle: a new full web bioinformatics framework. Bioinformatics 25 3005-3011. (doi:10.1093/bioinformatics/ btp493)

Nunes DP, Keates AC, Afdhal NH \& Offner GD 1995 Bovine gall-bladder mucin contains two distinct tandem repeating sequences: evidence for scavenger receptor cysteine-rich repeats. Biochemical Journal 310 41-48.

O'Day-Bowman MB, Mavrogianis PA, Reuter LM, Johnson DE, Fazleabas AT \& Verhage HG 1996 Association of oviduct-specific glycoproteins with human and baboon (Papio anubis) ovarian oocytes and enhancement of human sperm binding to human hemizonae following in vitro incubation. Biology of Reproduction 54 60-69. (doi:10.1095/biolreprod54.1.60) 
Ortgies F, Klewitz J, Gorgens A, Martinsson G \& Sieme H 2012 Effect of procaine, pentoxifylline and trolox on capacitation and hyperactivation of stallion spermatozoa. Andrologia 44 (Suppl 1) 130-138. (doi:10.1111/ j.1439-0272.2010.01150.x)

Palmer E, Bezard J, Magistrini M \& Duchamp G 1991 In vitro fertilization in the horse. A retrospective study. Journal of Reproduction and Fertility. Supplement 44 375-384.

Parrish JJ, Krogenaes A \& Susko-Parrish JL 1995 Effect of bovine sperm separation by either swim-up or Percoll method on success of in vitro fertilization and early embryonic development. Theriogenology $\mathbf{4 4}$ 859-869. (doi:10.1016/0093-691X(95)00271-9)

Perez FA, Roma SM, Cabada MO \& Marini PE 2006 Sperm binding glycoprotein is differentially present surrounding the lumen of isthmus and ampulla of the pig's oviduct. Anatomy and Embryology 211 619-624. (doi:10.1007/s00429-006-0114-0)

Prakobphol A, Xu F, Hoang VM, Larsson T, Bergstrom J, Johansson I, Frangsmyr L, Holmskov U, Leffler H, Nilsson C et al. 2000 Salivary agglutinin, which binds Streptococcus mutans and Helicobacter pylori, is the lung scavenger receptor cysteine-rich protein gp-340. Journal of Biological Chemistry 275 39860-39866. (doi:10.1074/jbc.M006928200)

Romar R, Coy P, Campos I, Gadea J, Matas C \& Ruiz S 2001 Effect of co-culture of porcine sperm and oocytes with porcine oviductal epithelial cells on in vitro fertilization. Animal Reproduction Science 68 85-98. (doi:10.1016/S0378-4320(01)00133-6)

Rossez Y, Coddeville B, Elass E, Quinchon JF, Vidal O, Corfield AP, Gosset P, Lacroix JM, Michalski JC \& Robbe-Masselot C 2011 Interaction between DMBT1 and galectin 3 is modulated by the structure of the oligosaccharides carried by DMBT1. Biochimie 93 593-603. (doi:10.1016/j.biochi.2010.12.002)

Takito J, Yan L, Ma J, Hikita C, Vijayakumar S, Warburton D \& Al-Awqati Q 1999 Hensin, the polarity reversal protein, is encoded by DMBT1, a gene frequently deleted in malignant gliomas. American Journal of Physiology 277 F277-F289.

Teijeiro JM \& Marini PE 2012a The effect of oviductal deleted in malignant brain tumor 1 over porcine sperm is mediated by a signal transduction pathway that involves pro-AKAP4 phosphorylation. Reproduction 143 773-785. (doi:10.1530/REP-11-0314)
Teijeiro JM \& Marini PE $2012 b$ S100A7 is present in human sperm and a homologous pig sperm protein interacts with sperm-binding glycoprotein (SBG). Andrologia 44 (Suppl 1) 772-779. (doi:10.1111/j. 1439-0272.2011.01264.x)

Teijeiro JM, Cabada MO \& Marini PE 2008 Sperm binding glycoprotein (SBG) produces calcium and bicarbonate dependent alteration of acrosome morphology and protein tyrosine phosphorylation on boar sperm. Journal of Cellular Biochemistry 103 1413-1423. (doi:10.1002/ jcb.21524)

Teijeiro JM, Roldan ML \& Marini PE 2012 Molecular identification of the sperm selection involved porcine sperm binding glycoprotein (SBG) as deleted in malignant brain tumors 1 (DMBT1). Biochimie 94 263-267. (doi:10.1016/j.biochi.2011.10.008)

Vijayakumar S, Erdjument-Bromage H, Tempst P \& Al-Awqati Q 2008 Role of integrins in the assembly and function of hensin in intercalated cells. Journal of the American Society of Nephrology 19 1079-1091. (doi:10.1681/ASN.2007070737)

Way AL, Schuler AM \& Killian GJ 1997 Influence of bovine ampullary and isthmic oviductal fluid on sperm-egg binding and fertilization in vitro. Journal of Reproduction and Fertility 109 95-101. (doi:10.1530/jrf.0.1090095)

Wu W, Kemp BL, Proctor ML, Gazdar AF, Minna JD, Hong WK \& Mao L 1999 Expression of DMBT1, a candidate tumor suppressor gene, is frequently lost in lung cancer. Cancer Research 59 1846-1851.

Zamir N, Barkan D, Keynan N, Naor Z \& Breitbart H 1995 Atrial natriuretic peptide induces acrosomal exocytosis in bovine spermatozoa. American Journal of Physiology 269 E216-E221.

Zhang M, Hong H, Zhou B, Jin S, Wang C, Fu M, Wang S \& Xia G 2006 The expression of atrial natriuretic peptide in the oviduct and its functions in pig spermatozoa. Journal of Endocrinology 189 493-507. (doi:10.1677/ joe.1.06483)

Received 11 January 2013

First decision 18 February 2013

Revised manuscript received 21 May 2013

Accepted 28 May 2013 